\title{
Titlepage
}

\section{The Ontogeny of Robin Sequence}

Robrecht J.H. Logjes ${ }^{1}$, Corstiaan C. Breugem ${ }^{1}$, Gijs. Van Haaften ${ }^{2}$, Emma C. Paes ${ }^{1}$, Geoffrey

H. Sperber, ${ }^{3}$ Marie José H. van den Boogaard ${ }^{2}$, Peter G. Farlie ${ }^{4}$

1. Department of Plastic and Reconstructive Surgery, University Medical Center Utrecht, Wilhelmina Children's Hospital Utrecht, the Netherlands.

2. Department of Genetics, Center for Molecular Medicine, University Medical Center Utrecht, The Netherlands.

3. Faculty of Medicine and Dentistry, University of Alberta, Canada.

4. Murdoch Children's Research Institute, Royal Children's Hospital, Parkville, Australia.

1. Robrecht J.H. Logjes MD

$\mathrm{PhD}$ candidate

Department of Plastic and Reconstructive Surgery

University Medical Centre Utrecht/ Wilhelmina Children’s Hospital

PO Box 85090

3508 AB Utrecht, The Netherlands

Email: r.j.h.logjes@gmail.com

Tel. +31887555555

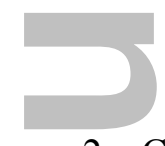

2. Corstiaan C. Breugem MD, PhD

Plastic and Reconstructive Surgeon

Department of Plastic and Reconstructive Surgery

This is the author manuscript accepted for publication and has undergone full peer review but has not been through the copyediting, typesetting, pagination and proofreading process, which may lead to differences between this version and the Version of record. Please cite this article as doi:10.1002/ ajmga.38718. 
University Medical Centre Utrecht/Wilhelmina Children’s Hospital

PO Box 85090

3508 AB Utrecht, The Netherlands

Email: c.c.breugem@umcutrecht.nl

Tel. +31887754572

3. Gijs van Haaften, $\mathrm{PhD}$

Associate Professor Center for Molecular Medicine

University Medical Center Utrecht

Universiteitsweg 100

3584 CG Utrecht, The Netherlands

Email: g.vanhaaften@umcutrecht.nl

Tel. $+31(0) 887567747$

rans

4. Emma C. Paes MD, PhD

Plastic and Reconstructive Surgeon

Department of Plastic and Reconstructive Surgery

University Medical Centre Utrecht/Wilhelmina Children's Hospital

PO Box 85090

3508 AB Utrecht, The Netherlands

Email: emmapaes@gmail.com

Tel. +31(0) 887754572

5. Geoffrey H. Sperber, BDS, MSc, PhD, FICD, Dr Med Dent (hc)

Faculty of Medicine and Dentistry, University of Alberta 
Edmonton, Alberta, T6G 1C9, Canada

Email: gsperber@ualberta.ca

(a)

6. Marie-Jose H. van den Boogaard MD, PhD

Clinical Geneticist

Department of Medical Genetics

University Medical Center Utrecht/Wilhelmina Children's Hospital

PO box 85090

3508 AB Utrecht, The Netherlands

Email: M.J.H.vandenBoogaard@umcutrecht.nl

Tel: +31 (0) 887553800

(1)

7. Peter G. Farlie, PhD

Director for Research in the Department of Plastic and Maxillofacial Surgery

Murdoch Childrens Research Institute, Royal Children's Hospital

Flemington Road, Parkville Victoria 3052 Australia

Email: peter.farlie@mcri.edu.au

Tel: +61 (3) 83416200

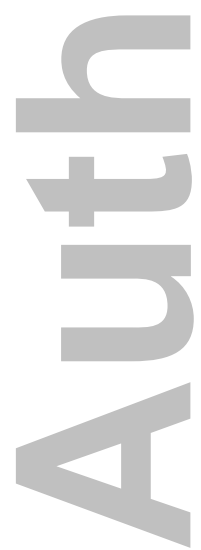

John Wiley \& Sons, Inc. 


\section{Corresponding Author}

Ro

Robrecht JH Logjes MD

$\mathrm{PhD}$ candidate

Department of Plastic and Reconstructive Surgery

University Medical Centre Utrecht/ Wilhelmina Children's Hospital

PO Box 85090

3508 AB Utrecht, The Netherlands

Email:r.j.h.logjes@gmail.com

Tel. $+31(0) 651028946$
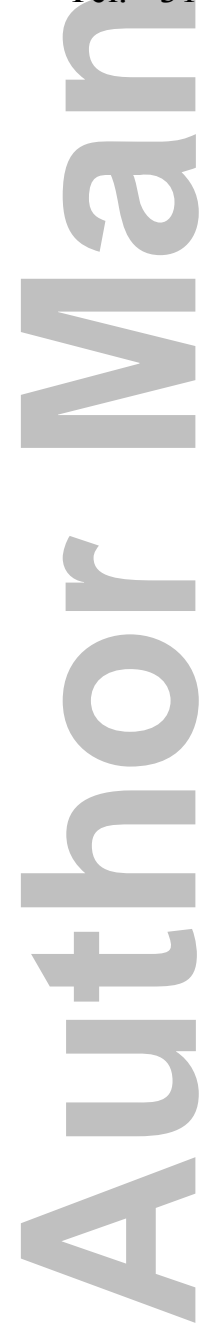

John Wiley \& Sons, Inc.

This article is protected by copyright. All rights reserved. 


\section{$\underline{\text { Manuscript }}$}

\section{Title:}

The Ontogeny of Robin Sequence
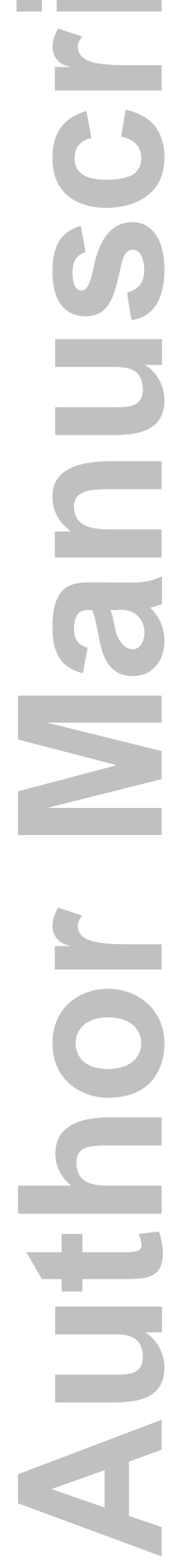

John Wiley \& Sons, Inc. 
The triad of micrognathia, glossoptosis and concomitant airway obstruction defined as "Robin sequence" (RS) is caused by oropharyngeal developmental events constrained by a reduced stomadeal space. This sequence of abnormal embryonic development also results in an anatomical configuration that might predispose the fetus to a cleft palate. RS is heterogeneous and many different etiologies have been described including syndromic, RS-plus, and isolated forms. For an optimal diagnosis, subsequent treatment and prognosis, a thorough understanding of the embryology and pathogenesis is necessary. This manuscript provides an update about our current understanding of the development of the mandible, tongue and palate and possible mechanisms involved in the development of RS. Additionally, we provide the reader with an up to date summary of the different etiologies of this phenotype and link this to the embryologic, developmental and genetic mechanisms.

Key Words: Robin sequence; Robin anomalad; embryology, micrognathia, glossoptosis, genetics

Running head: Logjes RJH et al. The Ontogeny of Robin Sequence. 


\section{INTRODUCTION}

The triad of micrognathia, glossoptosis and concomitant neonatal airway obstruction, currently known as Robin sequence, was first described by St. Hilaire in 1822, by Fairbain in 1846 and by Shukowsky in 1911(Fairbairn, 1846; Randall, 1977; St-Hilaire \& Buchbinder, 2000). The subsequent description in 1923 by the French Stomatologist Pierre Robin led to the eponymous definition of the condition (Robin, 1923). The condition was named Pierre Robin syndrome for nearly half a century, before better understanding lead to the identification of multiple etiologies that could result in the same clinical findings, which does not occur in a syndrome (St-Hilaire \& Buchbinder, 2000). Instead of syndrome, the term "sequence" was introduced, since the micrognathia subsequently resulted in glossoptosis and upper airway obstruction. It became widely accepted that the condition should be called "Pierre Robin sequence" and that the prior anomaly, the mandibular growth restriction, is pathogenetically heterogeneous (Sadewitz, 1992). In current literature the disorder is most commonly described as "Robin sequence" (RS) (Breugem \& Courtemanche, 2010; Breugem \& Mink van der Molen, 2009). Recently, an international consensus was achieved regarding the three features (micrognathia, glossoptosis and upper airway obstruction) that should be included in the diagnosis of RS (Breugem et al., 2016).

RS has an incidence of 1 in 8,000-14,000 newborns (Bush \& Williams, 1983; Printzlau \& Andersen, 2004; Vatlach, Maas, \& Poets, 2014) and the majority of cases may be associated with a syndrome, a chromosomal abnormality, or other additional anomalies, but may also occur as an isolated entity (Breugem \& Mink van der Molen, 2009; Holder-Espinasse et al., 2001; Izumi, Konczal, Mitchell, \& Jones, 2012; Xu et al., 2016).

Symptoms of RS include varying degrees of upper airway obstruction and feeding problems, possibly leading to subsequent life-threatening respiratory and cardiac sequelae and failure to thrive when not adequately treated (Costa et al., 2014; Van den Elzen, Semmekrot, Bongers, 
Huygen, \& Marres, 2001). Mortality rates of 1-26\% have been described (Costa et al., 2014;

Kaufman et al., 2016).

Numerous treatment options have been developed and vary according to severity.

Conservative interventions such as prone- or side positioning techniques, placement of a nasopharyngeal airway or pre-epiglottic baton, and continuous positive airway pressure (CPAP), is primarily applied (Abel, Bajaj, Wyatt, \& Wallis, 2012; Amaddeo et al., 2016; Buchenau et al., 2007; Evans et al., 2011; Poets \& Bacher, 2011). However if these are unsuccessful, surgical management such as tongue-lip-adhesion (TLA), mandibular distraction osteogenesis (MDO), subperiosteal release of the floor of the mouth, or tracheostomy may be considered (Evans et al., 2011).

Since it is well known that the RS is not only pathogenetically heterogeneous, but also phenotypically heterogeneous, it is possible that defining the specific cause could influence the treatment approach or may at least influence the prognosis (Cohen, 1999). The complex consequences of the RS glossopalatognathic malformations require a team of specialists to remedy the impaired airway and orognathic malfunction. This team of specialists might include molecular biologists, geneticists, embryologists, plastic surgeons, pediatricians, otolaryngologists, maxillofacial surgeons, dentists, orthodontists and speech pathologists. A better understanding of the etiopathogenesis and subsequent expectation of the potential mandibular development could result in better treatment for individual RS-patients.

It is important for all physicians involved in the care of children with RS to have a functional understanding of the embryology of RS. The aim of the current review is to focus on the embryology of the palate, mandible and the tongue. Moreover, information from molecular pathways and possible underlying syndrome diagnosis could improve our understanding of this phenomenon and will be discussed. 


\section{EMBRYOLOGY AND PRENATAL DEVELOPMENT}

Much of what we currently know about the origins of RS is based upon work done in zebra fish and murine models (Bhatia et al., 2015; Ghassibe-Sabbagh et al., 2011; Gordon et al., 2014; Swindell et al., 2015; Tan, Kilpatrick, \& Farlie, 2013; Yuan et al., 2012). While this information is important to identify the developmental mechanisms involved in RS, understanding normal human oral development is necessary to place these mechanistic insights into a clinically relevant perspective (Marques, Barbieri, \& Bettiol, 1998).

\section{Mandibular development}

During neural plate folding, cranial neural crest cells, which have the potential to differentiate into bones and connective tissue, will arise in the mid- and hindbrain regions and migrate ventrally to initiate the development of the first pharyngeal arch (which provides the embryonic maxillary and mandibular prominences) (Parada \& Chai, 2015; Sperber, Sperber, \& Guttmann, 2010d). Within the mandibular prominence, formation of the mandibular division of the trigeminal nerve is followed by the condensation of the ectomesenchyme, the multipotent cells derived from the cranial neural crest (Sperber, Sperber, \& Guttmann, 2010b). The process of condensation brings skeletal precursors into close association, thereby increasing cell-cell signaling required to initiate chondrogenesis and forms a primordial anlage for the ensuing skeletal element of the mandible (Hall \& Miyake, 2000) (Figure 1).

The first skeletal element formed within the mandibular process is Meckel's cartilage, which becomes the fundamental morphogenetic template of the mandible (Amano et al., 2010; Lee et al., 2001; Lorentowicz-Zagalak, Przystanska, \& Wozniak, 2005; Radlanski et al., 2016). Subsequent interaction of the ectomesenchyme with the mandibular arch epithelium results in an osteogenic membrane between days 36 and 38 of development (Figure 2). This osteogenic 
membrane lies lateral to the Meckel's cartilage, which forms between 41 and 45 days of development (Orliaguet, Dechelotte, Scheye, \& Vanneuville, 1993). In the region of the bifurcation of the inferior alveolar nerve and artery into its mental and incisive branches, a single ossification center for each half of the mandible will develop in the sixth week postconception (Sperber et al., 2010b). From here the process of intramembranous ossification, where the ectomesenchymal neural crest-derived osteoprogenitor cells differentiate directly into bone, results in formation of the mandibular ramus dorsally and the mandibular body ventrally. Eventually the bony tissue surrounds and invades the Meckel's cartilage in a proximal to distal direction and results in resorption of this cartilage skeleton dorsally from the mental foramen at the twenty-fourth week of development, while simultaneously intramembranous bony trabeculae are formed on the lateral side (Bender, Lipin, \& Goudy, 2018; Parada \& Chai, 2015; Sperber et al., 2010b). The mental and mandibular foramina, including the mandibular canal, are formed due to the prior presence of the inferior alveolar nerve and artery (Sperber et al., 2010b). At the site of the mandibular lingula this ossification process stops, although Meckel's cartilage persists and later forms the basis of two ear ossicles (the body and short crus of the incus, the head and neck of the malleus), the anterior ligament of the malleus and the sphenomandibular ligament (Amano et al., 2010; Bender et al., 2018; Sperber et al., 2010b; Sperber et al. 2010d). The only part of the mandible that directly derives from the Meckel's cartilage is the mental ossicle (Sperber et al., 2010d) (Figure 3).

Between the seventh and eight week post conception, the articular discs and presumptive condyle of the primitive temporomandibular joint arises, and by the eleventh week a recognizable joint capsule is formed (Merida-Velasco et al., 1999; Smartt, Low, \& Bartlett, 2005). A secondary mandibular cartilage, which is dissociated from Meckel's cartilage, develops between the tenth and fourteenth week post conception and results in the coronoid 
process and the head of the condyle. This secondary cartilage of the coronoid process assists in the development of the temporalis muscle and the additional intramembranous bone (Amano et al., 2010; Merida-Velasco et al., 1999; Sperber et al., 2010b). Secondary cartilage ossifies on both sides of the mental symphysis at seven months of development and within this fibrous tissue of the symphysis, mental ossicles arise which will assist the transformation from a syndesmosis into a synostosis in the first postnatal year (Sperber et al., 2010b). The secondary cartilage situated dorsal to the coronoid process is the precursor of the future condyle and arises at the tenth week post conception. These cartilage cells stimulate endochondral ossification of the condylar neck and are a stimulus for growth of the body and ramus of the mandible. Some of these cartilage cells will persist into adulthood, where they function as an articular surface in the temporomandibular joint or growth center for the mandibular condyle (Amano et al., 2010; Bender et al., 2018; Sperber et al., 2010b). After the development of these primary structures, the mandible will continue to grow, directly proportional to fetal weight and gestational age (Berraquero, Palacios, Gamallo, de la Rosa, \& Rodriguez, 1995).

\section{Development of the tongue}

The tongue develops in the fourth week post conception from the first pharyngeal arch in the ventral wall of the pharynx. At the same time medially and caudally of these lingual swellings and cranially of the foramen cecum, the tuberculum impar is formed (Figure $4 \& 5$ ). These lingual swellings merge with each other and form the anterior two thirds of the tongue, which is covered by ectodermally derived epithelium (Chen et al., 2009; Kulbersh \& Wiatrak, 2015; Sperber, Sperber, Guttmann, 2010c). The body of the tongue becomes separated from the oropharyngeal floor, except for the frenulum, by the degeneration of central cells, which results in the formation of a linguogingival groove. This process frees the body of the tongue 
and makes it highly mobile (Sperber et al., 2010c). The root of the tongue is formed by the copula and is covered by endodermally derived mucosa of the second, third and fourth pharyngeal arches (Chen et al., 2009; Kulbersh \& Wiatrak, 2015; Sperber et al., 2010c). The copula originates from the ventral bases of second, third and fourth pharyngeal arches and is a large midventral prominence just behind the tuberculum impar (Chen et al., 2009; Sperber et al., 2010c). At the site of fusion of the body and the root of the tongue, a V-shaped sulcus terminalis is formed (Kulbersh \& Wiatrak, 2015; Sperber et al., 2010c).

Eventually the tongue will grow rapidly and fill the whole stomodeal chamber, which will later develop into nasopharynx, oropharynx and mouth. Due to the growth of the stomodeal chamber and mandibular development, the tongue is able to descend relative to the roof of the chamber (Sperber et al., 2010c).

\section{Palatal development}

The secondary palate, which eventually divides the oral and nasal cavities into two independent chambers, originates as outgrowths from the oral surface of each of the maxillary processes known as the palatal shelves. The two palatal maxillary processes are initially located in a vertical position, with the tongue located between these two segments. Initial elongation of the palatal shelves is vertical, such that the growing edges of the shelves move parallel to each other towards the floor of the oral cavity. Oral volume increases as the elongation of the Meckel's cartilage and mandibular growth draws the tongue forward since the genioglossus muscle has its origin on the mental spine of the mandible and concomitant muscular development of the tongue converts it from a cylindrical to more flattened profile. Simultaneously, expansion of the tissue at the base of the palatal shelves due to changes in the extracellular matrix composition and cellular morphology generates a force, which pushes the tips of the shelves in a medial direction (Ferguson, 1978; Tang, Li, Jin, Lee, \& Jung, 2015; 
Yu, Karuppaiah, \& Ornitz, 2015). This tightly coordinated series of events allows the vertically orientated lateral palatal shelves to ascend to the level of the nasal septum and become horizontally opposite to each other (Price, Haddad, \& Fakhouri, 2016) (Figure 6).

The epithelium of both shelves makes their first contact at 8 weeks of development. This medial edge epithelium plays a key role in mediating the fusion of these lateral palatal shelves (Fitzpatrick, Denhez, Kondaiah, \& Akhurst, 1990; Proetzel et al., 1995; Smith, Lozanoff, Iyyanar, \& Nazarali, 2012; Tudela et al., 2002). By crucial processes of apoptosis and epitheliomesenchymal transformation this intervening epithelium gradually disappears, and a continuous structure is formed (Sperber, Sperber, Guttmann, 2010a; Tan \& Farlie, 2013). This process is initiated just behind the foramen incisivum and subsequently the secondary palate closes from anterior to dorsal. The palate subsequently develops as ectomesenchymal osteoprogenitors within the fused palatal shelves undergo intramembranous ossification (Smith et al., 2012; Sperber et al., 2010a). The primary palate, which is formed ventral to the foramen incisivum, is primarily derived from the frontonasal prominence and is not specifically involved in the pathogenesis of RS.

Except for the most posterior part of the palate, primary ossification centers of the maxillae and palatine bones form the hard palate (Ferguson, 1978; Sperber et al., 2010a). The soft palate derives from myogenic mesenchymal tissue of the first pharyngeal arch and fourth pharyngeal arch which respectively give rise to the tensor veli palatine muscle, innervated by the trigeminal nerve, and levator veli palatini, uvular and faucial pillar muscles innervated by the pharyngeal plexus and vagus nerve (Sperber et al., 2010a).

\section{UNDERSTANDING THE PATHOPHYSIOLOGY OF ROBIN SEQUENCE}

Although, RS is defined by a number of specific anatomical anomalies, there are many initiating events that could result in an RS-like phenotype. It is important to understand the 
range of known or suspected initiators since the prognosis for any particular individual will be greatly affected by the nature of the primary event responsible for restricting growth of the mandible.

It is imperative for clinicians to differentiate between RS-patients that have an identified underlying syndrome, from the isolated RS-group. The latter is characterized by RS-patients that only demonstrate the triad of micrognathia, glossoptosis and upper airway obstruction, without any concomitant anomalies. In addition, RS-patients that have additional anomalies or chromosomal defects but without a (yet) identified associated syndrome, are classified in the RS-plus group (Xu et al., 2016).

In RS it is believed that the reduced mandibular size can be the result of extrinsic abnormalities, intrinsic abnormalities or neurologic/neuromuscular abnormalities. During the first 6 weeks of development the fetal head is in a flexed position with the growing mandible close against the chest. The gradual extension of the head, until the 12th week of gestation, results in a normal outgrowth of the mandible. Head extension may be limited by oligohydramnios, multiple fetuses, uterine abnormalities, an abnormal embryonic implantation site, or unstretched uterine muscles within a small uterus, which could result in intrauterine restriction, possibly leading to micrognathia (Cohen, 1976; Mackay, 2011; Sadewitz, 1992). These can all be considered extrinsic causes of RS.

The intrinsic abnormalities include a range of known and unknown genetic influences which can result in syndromic, RS-plus or isolated forms, including syndromes like Treacher Collins syndrome, Stickler syndrome and many other syndromes which all result in a hypoplastic mandible due to Meckel's cartilage deficiencies (Sadewitz, 1992; Tan et al., 2013). The prognosis for the patient with isolated RS is likely to be very different to an individual with RS as part of a complex syndrome. On the other hand, understanding the underlying causes of 
syndromic RS might also provide clues for identifying novel etiologic mechanisms in isolated or RS-plus forms (Kaufman et al., 2016).

The ontogeny of the RS results from anomalies in the complex events of development of the palato-oropharyngeal area. The reduced size of the mandible that houses the tongue within its confines, results in the developing tongue being forced upwards and backwards into the now reduced stomadeal chamber concomitantly with growth of the embryonic palatal shelves (Figure 7). The backward fall of the base of the tongue is termed glossoptosis, a characteristic of the RS (Schweiger, Manica, \& Kuhl, 2016). At this time, mouth opening is normally a factor in withdrawing the tongue from its interposition between the vertical palatal shelves. This motor activity requires the gaping actions driven by the mylohyoid and digastric muscles attached to the Meckel's cartilage and innervated by the trigeminal nerve that may be compromised by any neuromotor deficiency. Continued growth of the mandible and subsequent mandibular morphology is also influenced by functional stresses placed on the mandible by the adjacent soft tissue, such as the developing masticatory and pharyngeal muscles (Pfaff, Metzler, Kim, \& Steinbacher, 2014).

Indeed, several neurologic or neuromuscular abnormalities are associated with micrognathia and diagnosed in RS (Abadie, Morisseau-Durand, Beyler, Manach, \& Couly, 2002; Baujat et al., 2001; Renault, Flores-Guevara, Soupre, Vazquez, \& Baudon, 2000). Reported neuromuscular disorders associated with RS are Congenital Myotonic Dystrophy (DM1; OMIM \#160900), Moebius syndrome (MB; OMIM 157900) and Carey-Fineman-Ziter syndrome (CFZ; OMIM 254940), characterized by Moebius sequence, RS and hypotonia (Tan et al., 2013). These examples suggest that in some cases RS may result from a primary neuromuscular deficit with the hypoplastic mandible resulting from a subsequent failure of reactive skeletal growth. 
As mentioned before, due to the glossoptosis and failure of tongue withdrawal in RS, the elevated intruding tongue can intervene between the vertical palatal shelves, preventing their normal elevation and lead to the development of a usually U-shaped cleft palate (Evans et al., 2011; Hanson \& Smith, 1975; Sperber et al., 2010a; Sperber \& Sperber, 2013) (Figure 8). The risk of developing a cleft palate seems to be related to the length of the mandible, with a doubling of the risk of clefting per millimeter reduction in mandible size (Hermann, Darvann, Ersboll, \& Kreiborg, 2014). In addition, a relation between reduced mandibular length and impaired tooth development has been suggested, since tooth agenesis is significantly more frequent in patients with RS (Andersson et al., 2015; Antonarakis \& Suri, 2014). Moreover, RS-patients with hypodontia and RS-patients without hypodontia, showed a different mandibular morphology, facial growth and long term dental arch length (Suri, Ross, \& Tompson, 2006). However, the high incidence of tooth agenesis in RS may also indicate a related etiology. The tissues forming the tooth and lip/palate derive from the same facial prominences as the mandible, and related signaling pathways regulate the morphogenesis of both structures (Tan et al., 2013). Thus, a primary defect in pharyngeal arch or morphogenetic signaling could impact both mandibular growth and tooth development.

It would be desirable to make a prognosis and treatment approach in each RS-infant individually based on their etiology and genetic diagnosis. Since the high heterogeneity of $\mathrm{RS}$, better understanding of the pathophysiology is crucial and should result in a more personalized treatment in every individual RS-infant. The increasing use of next-generation sequencing suggests a more etiological diagnosis in RS rather than a clinical diagnosis (Breugem et al., 2016). Subsequently, this could result in adjusting treatment protocols since treatment and prognosis for each individual RS-infant may differ. For example, up until now 
RS-infants are categorized by severity in order to determine the best treatment for respiratory distress in the neonatal period (Caouette-Laberge, Bayet, \& Larocque, 1994; Paes et al., 2015) This ranges from the RS-infant with respiratory distress that is manageable by previously described conservative options (prone and side positioning, nasopharyngeal airway and CPAP) to the RS-infant with severe respiratory distress that needs surgical treatment that includes traditional TLA or relatively new MDO (Abel et al., 2012; Evans et al., 2011; Poets \& Bacher, 2011). Recently, an increasing number studies reported on the outcomes of these surgical techniques and systematic review of the literature suggested that MDO might be more effective in relieving the airway obstruction compared to TLA (Almajed et al., 2017). However, MDO is associated with potential complications and reports on long-term outcomes are limited (Paes et al., 2016). The association between the underlying etiological diagnosis and mandibular morphology and eventual mandibular growth (catch-up growth), might influence the surgical airway management. There has been a lot of controversy about the socalled " catch-up growth" in RS-patients. However, it has been demonstrated that most RSpatients do not achieve full outgrowth compared to the normal, non-cleft population (Laitinen \& Ranta, 1992; Suri, Ross, \& Tompson, 2010). It is still unclear which RS-patients achieve normal outgrowth and which RS-patients do not. Patients with Treacher Collins syndrome for instance, are notoriously known for their small mandibles. A recent study demonstrated with 30 cephalometric measurements that Treacher Collins patients are significantly different from normative data (Esenlik, Plana, Grayson, \& Flores, 2017). Another study reported on the comparison of craniofacial characteristics (assessed by lateral cephalograms) between 22q11.2 deletion syndrome and Stickler syndrome, both with or without RS. When comparing the $22 \mathrm{q} 11.2$ deletion patients with versus without RS, no significant difference was observed for any of the 50 measurements. This suggests that the RS-features in the $22 \mathrm{q} 11.2$ deletion syndrome may be the result of hypotonia rather than any craniofacial or physical 
obstruction of the airway. The comparison of Stickler syndrome plus RS versus 22q11.2 deletion plus RS demonstrated two skeletal and eight airway measures to be significantly different. The authors state that Stickler and 22q11.2 deletion syndrome are similar in craniofacial morphology but demonstrate marked differences in pharyngeal and airway morphology (Glander \& Cisneros, 1992). These cephalometric differences clearly indicate the necessity to differentiate between the different genetic diagnosis of patients with RS.

Only one report compared mandibular size and position in patients with RS based on the underlying diagnosis, and subsequently suggests a different treatment approach in airway management. An isolated RS-group was compared with a syndromic RS-group including 4 common syndromic types of RS: Stickler syndrome, 22q11.2 deletion syndrome, Treacher Collins syndrome, and hemifacial microsomia. Mandibular length was significantly shorter in the syndromic RS group compared to the isolated RS-group. The authors implicate a "thoughtful approach" for respiratory distress in RS. Stickler and 22q11.2 deletion syndrome patients are likely to demonstrate similar mandibular morphology compared to isolated RSpatients (Rogers, Lim, Mulliken, \& Padwa, 2009). This might advocated for conservative airway management with a nasopharyngeal airway or the use of TLA when facing severe respiratory distress in these RS-subgroups. The mandible in Treacher Collins and hemifacial microsomia was not expected to normalize, which suggests that these syndromic RS-patients are suitable candidates for MDO (Anderson, Netherway, Abbott, Moore, \& David, 2004; Rogers et al., 2009). However, RS is a very heterogeneous phenomenon and more insight in the genetic causes will likely provide more information about the pathophysiology of RS.

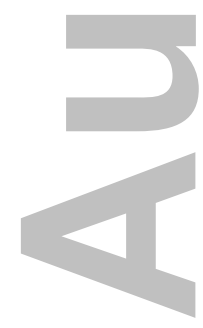




\section{GENETIC PERSPECTIVE}

An overview of the identified genes, gene functions \& expressions and phenotypes associated with Robin sequence are demonstrated in Table 1. Candidate genes associated with Robin sequence based on animal models are presented in Table 2.

Developmental gene networks in relation to underlying diagnoses

Craniofacial and tooth development is tightly controlled by the interaction of numerous signaling gene pathways (Bush \& Jiang, 2012; Depew, Simpson, Morasso, \& Rubenstein, 2005; Parada \& Chai, 2015; Sheehan-Rooney, Swartz, Lovely, Dixon, \& Eberhart, 2013).

The $D l x$ (distal-less homeobox) gene family gene family is essential for the development, patterning and morphogenesis of the pharyngeal arches forming a nested gene expression code analogous to the Hox-code (Depew et al., 2005). The Dlx5 and 6 genes constitute a major difference between the development of the maxilla and mandible (Parada \& Chai, 2015). Interestingly, studies in Dlx $5 / 6^{-/-}$mice demonstrated an agenesis of Meckel's cartilage and abnormal morphology of the mandible with the mandibular skeletal structures transformed into maxillae-like structures.

The identification of a mutation in DLX6 in a Nova Scotia Duck Tolling Retriever (NSDTR) dog breed, characterized by CP palate and micrognathia, similar to RS, support the role of DLX6 in the etiology of RS phenotype (Wolf et al., 2014) (Table 2). Subsequent analysis of $D L X 5$ and $D L X 6$ in patients with RS revealed a mutation within a highly conserved and functional region of $D L X 5$, suggesting the DLX5 gene might be involved in RS in humans (Wolf et al., 2014).

It has been demonstrated that Dlx 6 acts as a downstream effector of endothelin receptor type A (Ednra) signaling in the mouse. In Ednra-/- embryos, lower jaw structures undergo a homeotic transformation into maxillary-like structures (Ruest, Kedzierski, Yanagisawa, \& 
Clouthier, 2005; Ruest, Xiang, Lim, Levi, \& Clouthier, 2004). Recently, Gordon et al. identified EDNRA as the causative gene for mandibulofacial dysostosis with alopecia syndrome (MFDA, OMIM \#616367) involving mandibular hypoplasia, micrognathia, cleft palate and glossoptosis (Gordon et al., 2015). Interestingly, Ednra signaling is stimulated by endothelin 1 (Edn1), expressed in the overlying pharyngeal arch ectoderm (Clouthier et al., 2013). The EDN1 gene has been identified as the causative gene for recessive auriculocondylar syndrome (OMIM \#615706) and dominant isolated question-mark ears (OMIM \#612798) (Gordon et al., 2013), which can present with features of RS, like micrognathia and glossoptosis (Basart et al., 2015). Clouthier et al. reported that several familial cases of auriculocondylar syndrome were very mildly affected and may present with isolated micrognathia, suggesting that some sporadic cases of more frequent mandibular dysplasias such as RS may actually have an underlying genetic cause in common with that of auriculocondylar syndrome (Clouthier et al., 2013).

It also has been demonstrated that EDN1 is also necessary for Hand2 expression in the pharyngeal arch (Sasaki, Nichols, \& Kimmel, 2013; Tamura, Amano, \& Shiroishi, 2014). Hand2 is expressed in the first pharyngeal arch and plays a role in the dorsoventral/proximodistal pattern of the mandibular arch, but also initiates tongue morphogenesis (Barron et al., 2011; Parada \& Chai, 2015; Tamura et al., 2014; Yanagisawa, Clouthier, Richardson, Charite, \& Olson, 2003). In humans, the HAND2 gene resides at chromosome 4q. The clinical spectrum of $4 \mathrm{q}$ deletions is variable but commonly includes developmental delay, facial dysmorphic features, RS, and abnormalities of the cardiovascular, musculoskeletal and gastrointestinal systems. These patients with a $4 \mathrm{q}$ deletion suggest that the HAND2 gene might also be causative for mandibular hypoplasia and RS in humans (Strehle et al., 2012). 


\section{Cartilage and skeletal development}

During the earliest stages of mandibular morphogenesis, skeletal development starts with the formation of the rod-shaped Meckel's cartilage, by condensation of the cranial neural crest cell-derived mesenchyme (Radlanski et al., 2016). The Sox9 transcription factor has been shown to be essential for multiple steps in the chondrogenesis pathway from initiation of condensation through to control of extracellular matrix gene expression. (Barna \& Niswander, 2007; Jakobsen et al., 2007; Oh et al., 2014). In mice, conditional loss of Sox9 in neural crest cells result in complete absence of Meckel's cartilage. Furthermore, Sox9-null neural crest cells are unable to contribute to chondrogenic mesenchymal condensations. This disruption results in a diminished template of cartilage for the subsequent intramembranous osteogenesis that provides for the bony development of the mandible (Figure 2). The small mandible subsequently leads to the retruded tongue, obstructing the oropharyngeal airway similar to RS (Mori-Akiyama, Akiyama, Rowitch, \& De Crombrugghe, 2003).

In humans, intragenic mutations in SOXY leads to the semi-lethal skeletal dysplasia Campomelic Dysplasia (CD; OMIM \#114290), characterized by RS, shortening and anterior bowing of the long bones (campomelia), a bell-shaped chest with eleven pair ribs, scoliosis, narrow iliac wings, ossification delay of pubis and cervical vertebrae and club feet (Foster et al., 1994; Houston et al., 1983; Wagner et al., 1994). SOX9 mutations with residual function of the SOX9 protein has been associated with an attenuated form known as acampomelic campomelic dysplasia, without bending of the long bones, but with micro- and/or retrognathia, glossoptosis and cleft palate (Gopakumar et al., 2014; Staffler et al., 2010). Disruption of putative regulatory elements upstream of SOX9 has been reported in patients with Campomelic dysplasia and acampomelic campomelic dysplasia, but also in patients with isolated RS (Benko et al., 2009; Castori et al., 2016; Gordon et al., 2014). There appears to be a correlation with increased distance of the disruption from SOX9 and the severity of the 
phenotypes with the most distant disruptions associated with RS (Gordon et al., 2009; Selvi \& Mukunda-Priyanka, 2013; Rainger et al., 2014). While, the full implications of these distant chromosomal anomalies for skeletal development are unclear, identification of a 17q24 chromosomal anomaly in an individual with non-syndromic RS should prompt a close examination for additional skeletal features.

The nearest gene located upstream of $S O X 9$ is the potassium channel KCNJ2. Mutations in this gene are responsible for Andersen-Tawil syndrome (OMIM \#170390) characterized by periodic paralysis, cardiac arrhythmias, short stature scoliosis and distinctive dysmorphic facial features, including hypoplastic mandible and in some cases cleft palate (Plaster et al., 2001). Interestingly, $K C J N 2$ is expressed in facial primordia and was shown to be important for patterning of craniofacial genes and facial development as well as for in vitro muscle differentiation (Hinard, Belin, Konig, Bader, \& Bernheim, 2008). Whether abnormal muscle development results in the mandibular hypoplasia and cleft palate in patients with the Andersen-Tawil syndrome remains to be elucidated but this data is supportive of a potential role for KCNJ2 mis-regulation in the etiology of RS associated with 17q24 anomalies.

Mutations in the SOX9-regulated collagen genes COL2A1, COL11A1 and COL11A2 are associated with respectively Stickler syndrome type 1 (OMIM \#108300), type 2 (OMIM \#604841) and type 3 (OMIM \#184840) and reported as a common cause of RS (Basart et al., 2015; Izumi et al., 2012). Stickler syndrome is characterized by ocular findings, mainly myopia, mild spondyloepiphyseal dysplasia, and early-onset osteoarthritis and is the syndrome most commonly associated with RS, consistent with a Meckel's cartilage-based etiology.

John Wiley \& Sons, Inc. 
SOX9 also plays a role in regulating the expression of the $S A T B 2$ gene, by binding a cisregulatory element (CRE) upstream of SATB2 (Rainger et al., 2014) Interestingly, loss of function mutations in SATB2 leads to micrognathia and cleft palate in both mice and human (Britanova et al., 2006; Rainger et al., 2014). SATB2 is a nuclear matrix protein with a central role in the transcriptional network that regulates craniofacial pattern by chromatin remodeling and transcriptional regulation of transcription factors involved in osteoblasts differentiation (Dobreva et al., 2006; Leoyklang et al., 2013). Mouse studies showed that Satb2 is expressed in the developing jaw and loss of Satb2 leads to apoptosis in the distal jaw mesenchyme. It is suggested that Satb2 is required for survival of distal jaw precursors (Fish, 2016). In humans, chromosome $2 \mathrm{q} 32-\mathrm{q} 33$ deletions and translocations, including the SATB2 gene, as well as mutations in the coding region of SATB2 or in the CRE's upstream of SATB2 cause a recognizable syndromic form of $\mathrm{RS}$, associated with intellectual disability, cleft palate, micrognathia, small mouth, arachnodactyly and facial dimorphisms (OMIM \#612313) (Docker et al., 2014; Rainger et al., 2014).

\section{(1)}

In addition to collagens, proteoglycans are the main components of cartilage (Parada \& Chai, 2015). Defects in proteoglycan generation and processing are associated with a number of conditions that feature RS.

The SLC26A2 gene encodes a widely distributed sulfate/chloride antiporter required for proteoglycan sulfation. Slc26a2 mutant mice studies confirmed a dramatic decrease in sulfated proteoglycans, but also alterations in the organization of type II and type X collagen fibers, and premature onset of mineralization of the cartilage of the growth plates (Cornaglia, Casasco, Casasco, Riva, \& Necchi, 2009). The identification of compound heterozygous SLC26A2 mutation in two sisters with RS and mild limb shortening, accelerated carpal ossification, and multiple epiphyseal dysplasia, supports the hypothesis that a proteoglycan 
sulfation defect, might be an underlying mechanism in the etiology in RS (Zechi-Ceide, Moura, Raskin, Richieri-Costa, \& Guion-Almeida, 2013). Mutation of SLC26A2 is also associated with a spectrum of autosomal recessive chondrodysplasias, the most common of these, diastrophic dysplasia (DTD; OMIM \# 222600), has been reported as an RS-associated skeletal dysplasia (Tan et al., 2013).

Similarly, mutations in the IMPADI gene, involved in proteoglycan sulfation, result in the GPAPP type of chondrodysplasia with joint dislocations (OMIM \#614078). The two patients reported with this diagnosis presented with severe growth retardation with short and abnormal extremities, RS, knee hyperlaxity and abnormally shaped phalanges due to accessory hand bones (Nizon et al., 2012). The features in these patients show a clear overlap with CatelManzke syndrome (CATMANS; OMIM \#616145), characterized by RS combined with a unique form of bilateral hyperphalangy, causing a clinodactyly of the index finger resulting from mutation of the TGDS gene, which has also been linked to proteoglycan synthesis and sulfation (Ehmke et al., 2014).

\section{Defects in ubiquitous cellular processes resulting in RS-related conditions}

There is a growing number of craniofacial syndromes and congenital anomalies resulting from mutations in apparently fundamental cellular systems which might be predicted to have a global impact yet result in specific craniofacial and related defects.

The otopalatodigital (OPD) spectrum syndromes arise due to gain-of-function mutations of FLNA (Clark, Sawyer, Robertson, \& Sutherland-Smith, 2009; Robertson, 2007). FLNA crosslinks cytoskeletal actin into a three dimensional network to stabilize the cytoskeleton, but also interacts with many signaling molecules to regulate changes in cell shape, migration, growth and cell differentiation (Clark et al., 2009; Nakamura, Stossel, \& Hartwig, 2011; Song 
et al., 2016). OPD2 (OMIM 304120) often involves a cleft palate and micrognathia as well as a severe skeletal dysplasia raising the possibility of a phenotypic overlap with RS (Robertson, 2007).

Cerebrocostomandibular syndrome (CCMS; OMIM \#117650) is characterized by RS and posterior rib defects, ranging from rib gaps to complete absence of ossification (Lehalle et al., 2015). The identification of CDG type II with a mutation in COG1 (component of oligomeric golgi complex 1, involved in glycosylation) in patients with RS and features resembling cerebrocostomandibular syndrome revealed that a metabolic disorder might also be the underlying cause of RS (Zeevaert et al., 2009). Curiously, CCMS is also caused by mutation in $S N R P B$, encoding the small nuclear ribonucleoprotein polypeptides B and B1 and a core component of the spliceosome required for processing of pre-mRNA into the mature mRNA form in all cells (Bacrot et al., 2015).

Other mandibular facial dysostosis disorders associated with RS caused by mutations in genes involved in spliceosome function are: Mandibulofacial dysostosis, Guion-Almeida type (MFDGA, OMIM \#610536) associated with mutation in EFTUD2; Nager type of acrofacial dysostosis (AGD1, OMIM \#154400) by mutations in SF3B4; Richieri-Costa - Pereira syndrome (RCPS; \# MIM 268305) caused by mutations in EIF4A3. Similarly, TARP syndrome (TRPS, OMIM 311900, characterized by RS, talipes equinovarus, atrial septal defect and persistence of left superior vena cava) has been shown to result from mutation of $R B M 10$, which associates with the spliceosomal complex and regulates alternative splicing of the pre-mRNA by enhanced exon skipping (Wang et al., 2013).

The most frequent mandibulofacial dystosis syndrome Treacher-Collins syndrome (TCS; \#OMIM 154500) is caused by mutations in TCOF1, POLR1D or POLR1C, which are 
involved in ribosome biogenesis. The ribosome is a sub-cellular organelle required for synthesis of proteins and is required by all cells, yet mutation of TCOF1 results in widespread death of cranial neural crest cells required to construct the facial skeleton (Dixon et al., 2006).

The presentation of Treacher Collins syndrome is highly variable and a small mandible, cleft palate and respiratory obstruction can be interpreted as RS.

Furthermore, mutations in $\mathrm{DHODH}$, encoding an enzyme required for de novo pyrimidine biosynthesis, cause postaxial acrofacial dysostosis (POADS; OMIM \#263750), also known as Miller syndrome. Miller syndrome is a rare autosomal recessive disorder characterized clinically by severe micrognathia, cleft lip and/or palate, hypoplasia or aplasia of the postaxial elements of the limbs, coloboma of the eyelids and supernumerary nipples (Rainger et al., 2012). Pyrimidine synthesis is essential for RNA and DNA production and protein synthesis and is therefore crucial for growth and development.

Interestingly, a deletion on chromosome $22 \mathrm{q} 11.2$ is believed to be one of the most frequent associated syndromes in RS, with reported frequencies up to $13 \%$ in the RS-population (Shprintzen, 1988). Mutations in the TBX1-gene disturb normal migration of the cervical neural crest cells into the derivatives of the pharyngeal arches and cause the phenotypes Velocardiofacial syndrome (OMIM \#192430) and DiGeorge syndrome (OMIM \#188400). However, two recent studies that investigated large cohorts of RS-patients on genetic diagnosis reported low frequencies of $22 \mathrm{q} 11.2$ deletions $(1.5 \%$ and $1 \%$ ), indicating the importance of genetic re-evaluation of syndromic, isolated and RS-plus patients (Basart et al., 2015; Gomez-Ospina \& Bernstein, 2016).

Despite the tissue-specific nature of these craniofacial defects and syndromic forms of RS, they appear to result from defects in fundamental and essential processes such as DNA, RNA and protein synthesis and regulation of gene expression. Thus, while these syndromic forms 
of RS present with an array of additional features, one might hypothesize that the mechanisms underlying these syndromic presentations may also play a role in cases of isolated or RS-plus patients.

\section{CONCLUSION}

The advent of exome sequencing approaches to gene identification for genetic diseases continues to produce a wealth of new data on the etiology of craniofacial dysmorphology. In the wake of this new knowledge it is important to review our current understanding of the embryology and development of the mandible, tongue and palate and to facilitate identification of possible mechanisms involved in the development of RS. Both the primary skeletal origin of RS resulting in a hypoplastic mandible and the hypoplastic mandible due to extrinsic abnormalities are widely accepted in most RS-patients. However, oropharyngeal hypotonia, caused by a dysfunction of the brainstem or other structures, might also result in a hypoplastic mandible. More research of the neurological anomalies in RS-patients would be useful. Additionally, the genetic aberrations associated with RS are diverse, and demonstrate the numerous pathways and mechanisms, which may result in the same developmental outcome. Focusing more on the etiological diagnosis should eventually result in a more personalized approach in each individual RS-patient. While there have been a number of recent molecular diagnoses regarding syndromic forms of RS, progress with isolated and RSplus forms remains limited. It is hoped that revisiting the developmental anatomy in the context of these new genetic findings will prompt further consideration of the etiology of the isolated and RS-plus manifestation in RS. 


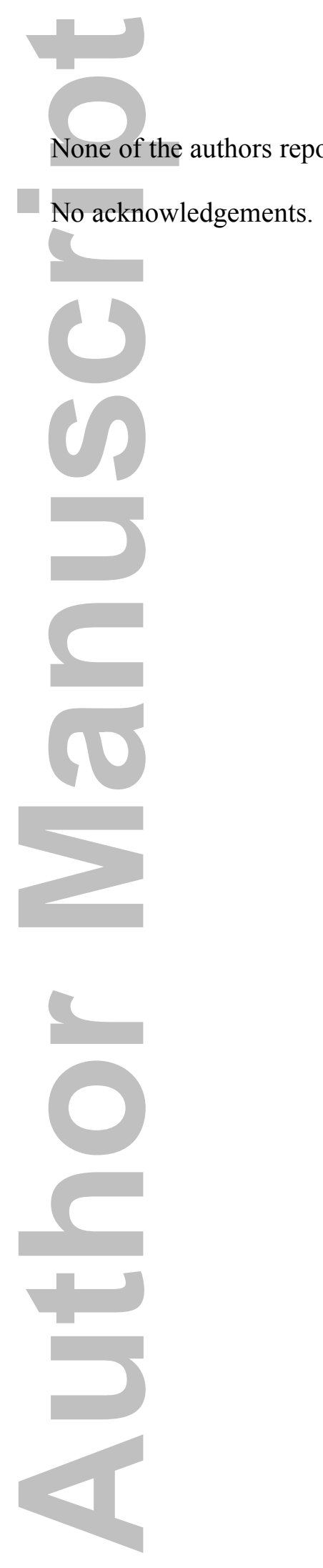

\section{ACKNOWLEDGEMENTS}

John Wiley \& Sons, Inc.

This article is protected by copyright. All rights reserved. 


\section{REFERENCES}

Abadie, V., Morisseau-Durand, M.P., Beyler, C., Manach, Y., \& Couly., G. (2002).

Brainstem dysfunction: a possible neuroembryological pathogenesis of isolated Pierre Robin sequence. European Journal of Pediatrics, 161, 275-280. doi:10.1007/s00431-002-0936-6

Abel, F., Bajaj, Y., Wyatt, M., Wallis, C. (2012). The successful use of the nasopharyngeal airway in Pierre Robin sequence: an 11-year experience. Archives of Disease in Childhood, 97, 331-334.

doi:10.1136/archdischild-2011-301134

Almajed, A., Viezel-Mathieu, A., Gilardino, M.S., Flores, R.L., Tholpady, S.S., Cote, A. (2017). Outcome Following Surgical Interventions for Micrognathia in Infants With Pierre Robin Sequence: A Systematic Review of the Literature. Cleft PalateCraniofacial Journal, 54, 32-42. doi: 10.1597/15-282

Amaddeo, A., Abadie, V., Chalouhi, C., Kadlub, N., Frapin, A., . . Picard Fauroux, B. (2016). Continuous Positive Airway Pressure for Upper Airway Obstruction in Infants with Pierre Robin Sequence. Plastic and Reconstructive Surgery, 137, 609-612. doi:10.1097/01.prs.0000475799.07597.23

Amano, O., Doi, T., Yamada, T., Sasaki, A., Sakiyama, K., . . Kindaichi K. (2010). Meckel's cartilage: discovery, embryology and evolution: overview of the specificity of Meckel's Cartilage. Journal of Oral Biosciences, 52, 125-135.

Anderson, P.J., Netherway, D.J., Abbott, A., Moore, M., \& David, D.J. (2004). Mandibular lengthening by distraction for airway obstruction in treacher-collins syndrome: the longterm results. Journal of Craniofacial Surgery, 15, 47-50.

Andersson, E.M., Feragen, K.B., Mikalsen, D., Kaul, J., Holla, T.M., \& Filip, C. (2015). Bilateral Hypodontia in Adolescents With Pierre Robin Sequence. Cleft PalateCraniofacial Journal, 52, 452-457. doi:10.1597/AAID-JOI-D-11-00190

Ansari, M., Rainger, J.K., Murra, J.E., Hanson, I., Firth, H.V., . . FitzPatrick, D.R. (2014). A syndromic form of Pierre Robin sequence is caused by 5q23 deletions encompassing FBN2 and PHAX. European Journal of Medical Genetics, 57, 587-595. doi: 10.1016/j.ejmg.2014.08.007

Antonarakis, G.S., \& Suri, S. (2014). Prevalence and patterns of permanent tooth agenesis in patients with nonsyndromic Pierre Robin sequence. American Journal of Orthodontics and Dentofacial Orthopedics, 145, 452-460. doi:10.1016/j.ajodo.2013.11.021

Bacrot, S., Doyard, M., Huber, C., Alibeu, O., Feldhahn, N., . . Cormier-Daire, V. (2015). Mutations in SNRPB, encoding components of the core splicing machinery, cause cerebro-costo-mandibular syndrome. Human Mutation, 36, 187-190. doi:10.1002/humu.22729

Barna, M., \& Niswander, L. (2007). Visualization of cartilage formation: insight into cellular properties of skeletal progenitors and chondrodysplasia syndromes. Developmental Cell, $12,931-941$. doi:10.1016/j.devcel.2007.04.016

Barron, F., Woods, C., Kuhn, K., Bishop, J., Howard, M.J., \& Clouthier, D.E. (2011).

Downregulation of Dlx 5 and Dlx6 expression by Hand 2 is essential for initiation of tongue morphogenesis. Development, 138, 2249-2259. doi:10.1242/dev.056929

Basart, H., Paes, E.C., Maas, S.M., van den Boogaard, M.J., van Hagen, J.M., . . . Hennekam, 
R.C. (2015). Etiology and pathogenesis of robin sequence in a large Dutch cohort.

American Journal of Medical Genetics Part A, 167A, 1983-1992.

doi:10.1002/ajmg.a.37154

Baujat, G., Faure, C., Zaouche, A., Viarme, F., Couly, G., \& Abadie, V. (2001).

Oroesophageal motor disorders in Pierre Robin syndrome. Journal of Pediatric Gastroenterology and Nutrition, 32, 297-302.

Bender, M.E., Lipin, R.B., \& Goudy, S.L. (2018). Development of the Pediatric

Temporomandibular Joint. Oral \& Maxillofacial Surgery Clinics of North America, 30, $1-9$.

doi:10.1016/j.coms.2017.09.002

Benko. S., Fantes, J.A., Amiel, J., Kleinjan, D.J., Thomas, S., . . Lyonnet, S. (2009). Highly conserved non-coding elements on either side of SOX9 associated with Pierre Robin sequence. Nature Genetics, 41, 359-364.

doi:10.1038/ng.329

Berraquero, R., Palacios, J., Gamallo, C., de la Rosa, P., \& Rodriguez, J.I. (1995). Prenatal growth of the human mandibular condylar cartilage. American Journal of Orthodontics and Dentofacial Orthopedics, 108, 194-200.

Bhatia, S., Gordon, C.T., Foster, R.G., Melin, L., Abadie, V., . . Kleinjan, D.A. (2015). Functional assessment of disease-associated regulatory variants in vivo using a versatile dual colour transgenesis strategy in zebrafish. PLOS Genetics, 11, e1005193. doi:10.1371/journal.pgen.1005193

Breugem, C.C., Evans, K.N., Poets, C.F., Suri, S., Picard, A., . . Hong, P. (2016). Best Practices for the Diagnosis and Evaluation of Infants With Robin Sequence: A Clinical Consensus Report. JAMA Pediatrics, 170, 894-902. doi:10.1001/jamapediatrics.2016.0796

Breugem, C.C. \& Courtemanche, D.J. (2010). Robin sequence: clearing nosologic confusion. Cleft Palate-Craniofacial Journal, 47, 197-200. doi:10.1597/08-061.1

Breugem, C.C. \& Mink van der Molen, A.B. (2009). What is "Pierre Robin sequence"? Journal of Plastic, Reconstructive \& Aesthetic Surgery, 62, 1555-1558. doi:10.1016/j.bjps.2008.06.050

Britanova, O., Depew, M.J., Schwark, M., Thomas, B.L., Miletich, I., . . Tarabykin, V. (2006). Satb2 haploinsufficiency phenocopies 2q32-q33 deletions, whereas loss suggests a fundamental role in the coordination of jaw development. American Journal of Human Genetics, 79, 668-678.

doi: $10.1086 / 508214$

Buchenau, W., Urschitz, M.S., Sautermeister, J., Bacher, M., Herberts, T., . . Poets, C.F. (2007). A randomized clinical trial of a new orthodontic appliance to improve upper airway obstruction in infants with Pierre Robin sequence. Journal of Pediatrics, 151, $145-149$. doi:10.1016/j.jpeds.2007.02.063

Bush, J.O. \& Jiang, R. (2012). Palatogenesis: morphogenetic and molecular mechanisms of secondary palate development. Development, 139, 231-243. doi:10.1242/dev.067082

Bush, P. \& Williams, A. (1983). Incidence of the Robin Anomalad (Pierre Robin syndrome). British Journal of Plastic Surgery, 36, 434-437.

Caouette-Laberge, L., Bayet, B., \& Larocque, Y. (1994). The Pierre Robin sequence: review of 125 cases and evolution of treatment modalities. Plastic and Reconstructive Surgery, 93, 934-942.

Castori, M., Bottillo, I., Morlino, S., Barone, C., Cascone, P., . . Laino, L. (2016). Variability 
in a three-generation family with Pierre Robin sequence, acampomelic campomelic dysplasia, and intellectual disability due to a novel approximately $1 \mathrm{Mb}$ deletion upstream of SOX9, and including KCNJ2 and KCNJ16. Birth Defects Research Part A: Clinical and Molecular Teratology, 106, 61-68. doi:10.1002/bdra.23463

Chen, E.H., Reid, R.R., Chike-Obi, C., Minugh-Purvis, N., Whitaker, L.A., . . Bartlett, S,P. (2009). Tongue dysmorphology in craniofacial microsomia. Plastic and Reconstructive Surgery, 124, 583-589.

doi:10.1097/PRS.0b013e3181addba9

Clark, A.R., Sawyer, G.M., Robertson, S.P., \& Sutherland-Smith, A.J. (2009). Skeletal dysplasias due to filamin A mutations result from a gain-of-function mechanism distinct from allelic neurological disorders. Human Molecular Genetics, 18, 4791-4800. doi:10.1093/hmg/ddp442

Clouthier, D.E., Passos-Bueno, M.R., Tavares, A.L., Lyonnet, S., Amiel, J., \& Gordon, C.T. (2013). Understanding the basis of auriculocondylar syndrome: Insights from human, mouse and zebrafish genetic studies. American Journal of Medical Genetics Part C: Seminars in Medical Genetics, 163, 306-317. doi:10.1002/ajmg.c.31376

Cohen, M.M. Jr. (1976). The Robin anomalad - its nonspecificity and associated syndromes. Journal of Oral Surgery, 34, 587-593.

Cohen, M.M. Jr. (1999). Robin sequences and complexes: causal heterogeneity and pathogenetic/phenotypic variability. American Journal of Medical Genetics, 84, 311 315.

Cornaglia, A. I., Casasco, A., Casasco, M., Riva, F., \& Necchi, V. (2009). Dysplastic histogenesis of cartilage growth plate by alteration of sulphation pathway: a transgenic model. Connective Tissue Research, 50, 232-242.

doi: $10.1080 / 03008200802684623$

Costa, M.A., Tu, M.M., Murage, K.P., Tholpady, S.S., Engle, W.A., \& Flores, R.L. (2014). Robin sequence: mortality, causes of death, and clinical outcomes. Plastic and Reconstructive Surgery, 134, 738-745. doi:10.1097/PRS.0000000000000510

Depew, M.J., Simpson, C.A., Morasso, M., \& Rubenstein, J.L. (2005). Reassessing the Dlx code: the genetic regulation of branchial arch skeletal pattern and development. Journal of Anatomy, 207, 501-561. doi: $10.1111 / j .1469-7580.2005 .00487 . x$

Dixon, J., Jones, N.C., Sandell, L.L., Jayasinghe, S.M., Crane, J., . . Trainor, P.A. (2006). Tcof1/Treacle is required for neural crest cell formation and proliferation deficiencies that cause craniofacial abnormalities. Proc Natl Acad Sci U S A, 103, 13403-13408. doi: 10.1073/pnas.0603730103

Dobreva, G., Chahrour, M., Dautzenberg, M., Chirivella, L., Kanzler, B., . . . Grosschedl, R.

(2006). SATB2 is a multifunctional determinant of craniofacial patterning and osteoblast differentiation. Cell, 125, 971-986. doi:10.1016/j.cell.2006.05.012

Docker, D., Schubach, M., Menzel, M., Munz, M., Spaich, C., . . Bartholdi, D. (2014). Further delineation of the SATB2 phenotype. European Journal of Human Genetics, 22, 1034-1039. doi:10.1038/ejhg.2013.280

Duan, X., Bradbury, S.R., Olsen, B.R., \& Berendsen, A.D. (2016). VEGF stimulates intramembranous bone formation during craniofacial skeletal development. Matrix Biology, 52-54, 127-140. 
doi: 10.1016/j.matbio.2016.02.005

Ehmke, N., Caliebe, A., Koenig, R., Kant, S.G., Stark, Z., . . Mundlos, S. (2014).

Homozygous and compound-heterozygous mutations in TGDS cause Catel-Manzke

syndrome. The American Journal of Human Genetics, 95, 763-770.

doi:10.1016/j.ajhg.2014.11.004

Esenlik, E., Plana, N.M., Grayson, B.H., \& Flores, R.L. (2017). Cephalometric Predictors of Clinical Severity in Treacher Collins Syndrome. Plastic and Reconstructive Surgery, 140, 1240-1249.

doi:10.1097/PRS.0000000000003853

Evans, K.N., Sie, K.C., Hopper, R.A., Glass, R.P., Hing, A.V., \& Cunningham, M.L. (2011). Robin sequence: from diagnosis to development of an effective management plan. Pediatrics, 127, 936-948. doi:10.1542/peds.2010-2615

Fairbairn, P. (1846). Suffocation in an infant from retraction of the base of the tongue, connected with the defect of the frenum. Monthly Journal of Medical Science, 6, 280281.

Ferguson, M.W. (1978). Palatal shelf elevation in the Wistar rat fetus. J Anat, 125, 555-577.

Fish, J.L. (2016). Developmental mechanisms underlying variation in craniofacial disease and evolution. Developmental Biology, 415, 188-197.

doi:10.1542/peds.2010-2615

Fitzpatrick, D.R., Denhez, F., Kondaiah, P., \& Akhurst, R.J. (1990). Differential expression of TGF beta isoforms in murine palatogenesis. Development, 109, 585-595.

Foster, J.W., Dominguez-Steglich, M.A., Guioli, S., Kwok, C., Weller, P.A., . . G Goodfellow, P.N. (1994). Campomelic dysplasia and autosomal sex reversal caused by mutations in an SRY-related gene. Nature, 372, 525-530. doi: $10.1038 / 372525 \mathrm{a} 0$

Ghassibe-Sabbagh, M., Desmyter, L., Langenberg, T., Claes, F., Boute, O., . . Vikkula, M.

(2011). FAF1, a gene that is disrupted in cleft palate and has conserved function in zebrafish. American Journal of Human Genetics, 88, 150-161. doi:10.1016/j.ajhg.2011.01.003

Glander, K., \& Cisneros, G.J. (1992). Comparison of the craniofacial characteristics of two syndromes associated with the Pierre Robin sequence. Cleft Palate-Craniofacial Journal, 29, 210-219.

Gomez-Ospina, N., \& Bernstein, J.A. (2016). Clinical, cytogenetic, and molecular outcomes in a series of 66 patients with Pierre Robin sequence and literature review: 22q11.2 deletion is less common than other chromosomal anomalies. American Journal of Medical Genetics Part A, 170, 870-880. doi:10.1002/ajmg.a.37538

Gopakumar, H., Superti-Furga, A., Unger, S., Scherer, G., Rajiv, P.K., \& Nampoothiri, S. (2014). Acampomelic form of campomelic dysplasia with SOX9 missense mutation.

Indian Journal of Pediatrics 81, 98-100. doi:10.1007/s12098-013-1007-x

Gordon, C.T., Attanasio, C., Bhatia, S., Benko, S., Ansari, M., . . Lyonnet, S. (2014). Identification of novel craniofacial regulatory domains located far upstream of SOX9 and disrupted in Pierre Robin sequence. Human Mutation, 35, 1011-1020. doi:10.1002/humu.22606

Gordon, C.T., Petit, F., Kroisel, P.M., Jakobsen, L., Zechi-Ceide, R.M., . . A Amiel, J. (2013). Mutations in endothelin 1 cause recessive auriculocondylar syndrome and dominant isolated question-mark ears. American Journal of Medical Geneticst, 93, 1118-1125. doi:10.1016/j.ajhg.2013.10.023 
Gordon, C.T., Tan, T.Y., Benko, S., Fitzpatrick, D., Lyonnet, S., \& Farlie, P.G. (2009). Longrange regulation at the SOX9 locus in development and disease. Journal of Medical Genetics, 46, 649-656. doi:10.1136/jmg.2009.068361

Gordon, C.T., Weaver, K.N., Zechi-Ceide, R.M., Madsen, E.C., Tavares, A.L., . . Amiel, J. (2015). Mutations in the endothelin receptor type A cause mandibulofacial dysostosis with alopecia. American Journal of Human Genetics, 96, 519-531. doi:10.1016/j.ajhg.2015.01.015

Hall, B.K., \& Miyake, T. (2000). All for one and one for all: condensations and the initiation of skeletal development. BioEssays, 22, 138-147. doi:10.1002/(SICI)1521-1878(200002)22:2<138::AID-BIES5>3.0.CO;2-4

Hanson, J.W., \& Smith, D.W. (1975). U-shaped palatal defect in the Robin anomalad: developmental and clinical relevance. Journal of Pediatrics, 87, 30-33.

Hermann, N.V., Darvann, T.A., Ersboll, B.K., \& Kreiborg, S. (2014). Short mandible - a possible risk factor for cleft palate with/without a cleft lip. Orthodontics \& Craniofacial Research, 17, 106-114. doi:10.1111/ocr.12036

Hinard, V., Belin, D., Konig, S., Bader, C.R., \& Bernheim, L. (2008). Initiation of human myoblast differentiation via dephosphorylation of Kir2.1 K+ channels at tyrosine 242. Development, 135, 859-867. doi:10.1242/dev.011387

Holder-Espinasse, M., Abadie, V., Cormier-Daire, V., Beyler, C., Manach, Y., . . Amiel, J. (2001). Pierre Robin sequence: a series of 117 consecutive cases. Journal of Pediatrics, 139, 588-590. doi: $10.1067 / \mathrm{mpd} .2001 .117784$

Houston, C.S., Opitz, J.M., Spranger, J.W., Macpherson, R.I., Reed, M.H., . . Schinzel, A. (1983). The campomelic syndrome: review, report of 17 cases, and follow-up on the currently 17-year-old boy first reported by Maroteaux et al in 1971. American Journal of Medical Genetics, 15, 3-28. doi:10.1002/ajmg.1320150103

Huang, H., Yang, X., Bao, M., Cao, H., Miao, X., . . Zhang, Z. (2016). Ablation of the Sox 11 Gene Results in Clefting of the Secondary Palate Resembling the Pierre Robin Sequence. Journal of Biological Chemistry, 291, 7107-7118. doi: 10.1074/jbc.M1 15.690875

Izumi, K., Konczal, L.L., Mitchell, A.L., \& Jones, M.C. (2012). Underlying genetic diagnosis of Pierre Robin sequence: retrospective chart review at two children's hospitals and a systematic literature review. Journal of Pediatrics, 160, 645-650. doi:10.1016/j.jpeds.2011.09.021

Jakobsen, L.P., Ullmann, R., Christensen, S.B., Jensen, K.E., Molsted, K., . . . Tumer, Z. (2007). Pierre Robin sequence may be caused by dysregulation of SOX9 and KCNJ2. Journal of Medical Genetics, 44, 381-386. doi:10.1136/jmg.2006.046177

Kaufman, M.G., Cassady, C.I., Hyman, C.H., Lee, W., Watcha, M.F., . . . Buchanan, E.P. (2016). Prenatal Identification of Pierre Robin Sequence: A Review of the Literature and Look towards the Future. Fetal Diagnosis and Therapy, 39, 81-89. doi: $10.1159 / 000380948$

Koczkowska, M., Wierzba, J., Śmigiel, R., Sąsiadek, M., Cabała, M., . . Lipska-Ziętkiewicz, B.S. (2017). Genomic findings in patients with clinical suspicion of 22q11.2 deletion syndrome. Journal of Applied Genetics, 58, 93-98.

doi: 10.1007/s13353-016-0366-1 
Kouskoura, T., El Fersioui, Y., Angelini, M., Graf, D., Katsaros, C., \& Chiquet, M. (2016).

Dislocated Tongue Muscle Attachment and Cleft Palate Formation. Journal of Dental Research, 95, 453-459.

doi: $10.1177 / 0022034515621869$

Kulbersh, B.D., \& Wiatrak, B.J. (2015). Pediatric lingual and other intraoral lesions. Otolaryngologic Clinics of North America, 48, 175-190.

doi:10.1016/j.otc.2014.09.012

Laitinen, S.H., \& Ranta, R.E. (1992). Cephalometric measurements in patients with Pierre Robin syndrome and isolated cleft palate. Scandinavian Journal of Plastic and Reconstructive Surgery and Hand Surgery, 26, 177-183.

Lee, S.K., Kim, Y.S., Oh, H.S., Yang, K.H., Kim, E.C., \& Chi, J.G. (2001). Prenatal development of the human mandible. Anatomical Record, 263, 314-325.

Lehalle, D., Wieczorek, D., Zechi-Ceide, R.M., Passos-Bueno, M.R., Lyonnet, S., . . . Gordon, C.T. (2015). A review of craniofacial disorders caused by spliceosomal defects. Clinical Genetics, 88, 405-415.

doi:10.1111/cge.12596

Leoyklang, P., Suphapeetiporn, K., Srichomthong, C., Tongkobpetch, S., Fietze, S., . . . Shotelersuk, V. (2013). Disorders with similar clinical phenotypes reveal underlying genetic interaction: SATB2 acts as an activator of the UPF3B gene. Human Genetics, 132, 1383-1393. doi:10.1007/s00439-013-1345-9

Ling, I.T., Rochard, L., \& Liao, E.C. (2017). Distinct requirements of wls, wnt9a, wnt5b and gpc4 in regulating chondrocyte maturation and timing of endochondral ossification. Developmental Biology, 421, 219-232. doi:10.1016/j.ydbio.2016.11.016

Lorentowicz-Zagalak, M., Przystanska, A., \& Wozniak, W. (2005). The development of Meckel's cartilage in staged human embryos during the 5th week. Folia Morphologica, 64, 23-28.

Mackay, D.R. (2011). Controversies in the diagnosis and management of the Robin sequence. Journal of Craniofacial Surgery, 22, 415-420. doi:10.1097/SCS.0b013e3182074799

Marques, I.L., Barbieri, M.A., \& Bettiol, H. (1998). Etiopathogenesis of isolated Robin sequence. Cleft Palate-Craniofacial Journal, 35, 517-525. doi:10.1597/1545-1569(1998)035<0517:EOIRS >2.3.CO;2

Merida-Velasco, J.R., Rodriguez-Vazquez, J.F., Merida-Velasco, J.A., Sanchez-Montesinos, I., Espin-Ferra, J., \& Jimenez-Collado, J. (1999). Development of the human temporomandibular joint. Anatomical Record, 255, 20-33.

Mori-Akiyama, Y., Akiyama, H., Rowitch, D.H., \& De Crombrugghe, B. (2003). Sox9 is required for determination of the chondrogenic cell lineage in the cranial neural crest. Proceedings of the National Academy of Sciences, 100, 9360-9365. doi:10.1073/pnas.1631288100

Nakamura, F., Stossel, T.P., \& Hartwig, J.H. (2011). The filamins: organizers of cell structure and function. Cell Adhesion \& Migration, 5, 160-169.

Nizon, M., Alanay, Y., Tuysuz, B., Kiper, P.O., Genevieve, D., . . Cormier-Daire, V. (2012). IMPAD1 mutations in two Catel-Manzke like patients. American Journal of Medical Genetics Part A, 158, 2183-2187. doi:10.1002/ajmg.a.35504

Oh, C., Lu, Y., Liang, S., Mori-Akiyama, Y., Chen, D., . . Yasuda, H. (2014). SOX9 regulates multiple genes in chondrocytes, including genes encoding ECM proteins, ECM modification enzymes, receptors, and transporters. PLoS ONE, 9, e107577. 
doi:10.1371/journal.pone.0107577

Orliaguet, T., Dechelotte, P., Scheye, T., \& Vanneuville, G. (1993). The relationship between Meckel's cartilage and the development of the human fetal mandible. Surgical and Radiologic Anatomy, 15, 113-118.

Paes, E.C., Bittermann, G.K., Bittermann, D., Muradin, M.S., van Hogezand, R., . . . Breugem, C.C. (2016). Long-Term Results of Mandibular Distraction Osteogenesis with a Resorbable Device in Infants with Robin Sequence: Effects on Developing Molars and Mandibular Growth. Plastic and Reconstructive Surgery, 137, 375e-385e.

doi:10.1097/01.prs.0000475769.06773.86

Paes, E.C., van Nunen, D.P., Speleman, L., Muradin, M.S., Smarius, B., . . Breugem, C.C. (2015). A pragmatic approach to infants with Robin sequence: a retrospective cohort study and presence of a treatment algorithm. Clinical Oral Investigations, 19, 21012114.

doi:10.1007/s00784-015-1407-6

Parada, C., \& Chai, Y. (2015). Mandible and Tongue Development. Current Topics in Developmental Biology, 115, 31-58.

doi:10.1016/bs.ctdb.2015.07.023

Parada, C., Han, D., Grimaldi, A., Sarrion, P., Park, S.S., . . Chai, Y. (2015). Disruption of the ERK/MAPK pathway in neural crest cells as a potential cause of Pierre Robin sequence. Development, 142, 3734-3745. doi: $10.1242 /$ dev. 125328

Pfaff, M.J., Metzler, P., Kim, Y., \& Steinbacher, D.M. (2014). Mandibular volumetric increase following distraction osteogenesis. Journal of Plastic, Reconstructive \& Aesthetic Surgery, 67, 1209-1214. doi:10.1016/j.bjps.2014.05.002

Plaster, N.M., Tawil, R., Tristani-Firouzi, M., Canun, S., Bendahhou, S., . . . Ptacek, L.J. (2001). Mutations in Kir2.1 cause the developmental and episodic electrical phenotypes of Andersen's syndrome. Cell, 105, 511-519.

Poets, C.F., \& Bacher, M. (2011). Treatment of upper airway obstruction and feeding problems in Robin-like phenotype. Journal of Pediatrics, 159, 887-892. doi:10.1016/j.jpeds.2011.07.033

Price, K.E., Haddad, Y., \& Fakhouri, W.D. (2016). Analysis of the Relationship Between Micrognathia and Cleft Palate: A Systematic Review. Cleft Palate-Craniofacial Journal, 53, 34-44. doi:10.1597/14-238

Printzlau, A., \& Andersen, M. (2004). Pierre Robin sequence in Denmark: a retrospective population-based epidemiological study. Cleft Palate-Craniofacial Journal, 41, 47-52. doi:10.1597/02-055

Proetzel, G., Pawlowski, S.A., Wiles, M.V., Yin, M., Boivin, G.P., . . Doetschman, T. (1995). Transforming growth factor-beta 3 is required for secondary palate fusion. Nature Geneticst, 11, 409-414. doi:10.1038/ng1295-409

Radlanski, R.J., Renz, H., Zimmermann, C.A., Schuster, F.P., Voigt, A., \& Heikinheimo, K. (2016). Chondral ossification centers next to dental primordia in the human mandible: A study of the prenatal development ranging between 68 to $270 \mathrm{~mm}$ CRL. Annals of Anatomy, 208, 49-57. doi:10.1016/j.aanat.2016.07.006

Rainger, J., Bengani, H., Campbell, L., Anderson, E., Sokhi, K., . . Fitzpatrick, D.R. (2012). Miller (Genee-Wiedemann) syndrome represents a clinically and biochemically distinct subgroup of postaxial acrofacial dysostosis associated with partial deficiency of 
DHODH. Human Molecular Genetics, 21, 3969-3983.

doi: $10.1093 / \mathrm{hmg} / \mathrm{dds} 218$

Rainger, J.K., Bhatia, S., Bengani, H., Gautier, P., Rainger, J., . . Fitzpatrick, D.R. (2014).

Disruption of SATB2 or its long-range cis-regulation by SOX9 causes a syndromic form of Pierre Robin sequence. Human Molecular Genetics, 23, 2569-2579. doi:10.1093/hmg/ddt647

Randall, P. (1977). The Robin anomalad: micrognathia and glossoptosis with airway obstruction. In: Converse JM, ed Reconstructive Plastic Surgery. Philadelphia: WB Saunders. pp. 2235-2224

Renault, F., Flores-Guevara, R., Soupre, V., Vazquez, M.P., \& Baudon, J.J. (2000). Neurophysiological brainstem investigations in isolated Pierre Robin sequence. Early Human Development, 58, 141-152.

Rieder, M.J., Green, G.E., Park, S.S., Stamper, B.D., Gordon, C.T., . . Cunningham, M.L. (2012). A human homeotic transformation resulting from mutations in PLCB4 and GNAI3 causes auriculocondylar syndrome. American Journal of Human Genetics, 90, 907-914. doi: 10.1016/j.ajhg.2012.04.002

Robertson, S.P. (2007). Otopalatodigital syndrome spectrum disorders: otopalatodigital syndrome types 1 and 2, frontometaphyseal dysplasia and Melnick-Needles syndrome.

European Journal of Human Genetics, 15, 3-9. doi:10.1038/sj.ejhg.5201654

Robin, P. (1923). La chute de la base de la langue considérée comme une nouvelle cause de gêne dans la respiration naso-pharyngienne. Bulletin De l'Academie De Medecine, 89, $37-41$.

Rogers, G.F., Lim, A.A., Mulliken, J.B., \& Padwa, B.L. (2009). Effect of a syndromic diagnosis on mandibular size and sagittal position in Robin sequence. Journal of Oral and Maxillofacial Surgery, 67, 2323-2331. doi:10.1016/j.joms.2009.06.010

Ruest, L.B., Kedzierski, R., Yanagisawa, M., \& Clouthier, D.E. (2005). Deletion of the endothelin-A receptor gene within the developing mandible. Cell and Tissue Research, 319, 447-453. doi:10.1007/s00441-004-0988-1

Ruest, L.B., Xiang, X., Lim, K.C., Levi, G., \& Clouthier, D.E. (2004). Endothelin-A receptordependent and -independent signaling pathways in establishing mandibular identity. Development, 131, 4413-4423.

doi:10.1242/dev.01291

Sadewitz, V.L. (1992). Robin sequence: changes in thinking leading to changes in patient care. Cleft Palate-Craniofacial Journal, 29, 246-253. doi:10.1597/1545-1569(1992)029<0246:RSCITL >2.3.CO;2

Sasaki, M.M., Nichols, J.T., \& Kimmel, C.B. (2013). Edn1 and hand2 Interact in early

regulation of pharyngeal arch outgrowth during zebrafish development. PLoS ONE, 8 , e67522.

doi:10.1371/journal.pone.0067522

Schweiger, C., Manica, D., \& Kuhl, G. (2016). Glossoptosis. Seminars in Pediatric Surgery, $25,123-127$. doi:10.1053/j.sempedsurg.2016.02.002

Selvi, R., \& Mukunda-Priyanka, A. (2013). Role of SOX9 in the Etiology of Pierre-Robin Syndrome. Iranian Journal of Basic Medical Sciences, 16, 700-704.

Sheehan-Rooney, K., Swartz, M.E., Lovely, C.B., Dixon, M.J., \& Eberhart, J.K. (2013). Bmp and Shh signaling mediate the expression of satb2 in the pharyngeal arches. PLoS ONE, 
8, e59533.

doi:10.1371/journal.pone.005953

Shprintzen, R.J. (1988). Pierre Robin, micrognathia, and airway obstruction: the dependency of treatment on accurate diagnosis. International Anesthesiology Clinics, 26, 64-71.

Smartt, J.M., Low, D.W., \& Bartlett, S.P. (2005). The pediatric mandible: I. A primer on growth and development. Plastic and Reconstructive Surgery, 116, 14e-23e.

Smith, T.M., Lozanoff, S., Iyyanar, P.P., \& Nazarali, A.J. (2012). Molecular signaling along the anterior-posterior axis of early palate development. Frontiers in Physiology, 3, 488. doi:10.3389/fphys.2012.00488

Song, M., He, Q., Berk, B.A., Hartwig, J.H., Stossel, T.P., \& Nakamura, F. (2016). An adventitious interaction of filamin A with RhoGDI2(Tyr153Glu). Biochemical and Biophysical Research Communications, 469, 659-664. doi:10.1016/j.bbrc.2015.12.044

Sperber, G.H., \& Sperber, S.M. (2013). Chapter 1: Embryogenetics of Cleft Lip and Palate. In: Berkowitz, S. Cleft Lip and Palate third edition. Berlin Heidelberg: Springer-Verlag. pp. 3-33

Sperber, G.H., Sperber, S.M., Guttmann, G.D. (2010a). Chapter 10: Palate. In: Craniofacial embryogenetics and development 2 nd ed. Shelton: People's medical publishing house. pp. 131-144.

Sperber, G.H., Sperber, S.M., Guttmann, G.D. (2010b). Chapter 12: Mandible. In: Craniofacial embryogenetics and development 2nd ed. Shelton: People's medical publishing house. pp. 149-151.

Sperber, G.H., Sperber, S.M., Guttmann, G.D. (2010c). Chapter 15: Tongue and Tonsils. In: Craniofacial embryogenetics and development 2nd ed. Shelton: People's medical publishing house. pp. 179-185.

Sperber, G.H., Sperber, S.M., Guttmann, G.D. (2010d). Chapter 4: Pharyngeal arches. In: Craniofacial embryogenetics and development 2 nd ed. Shelton: People's medical publishing house. pp. 61-67

St-Hilaire, H., \& Buchbinder, D. (2000). Maxillofacial pathology and management of Pierre Robin sequence. Otolaryngologic Clinics of North America, 33, 1241-1256.

Staffler, A., Hammel, M., Wahlbuhl, M., Bidlingmaier, C., Flemmer, A.W., . . . Holzinger, A. (2010). Heterozygous SOX9 mutations allowing for residual DNA-binding and transcriptional activation lead to the acampomelic variant of campomelic dysplasia. Human Mutation, 31, 1436-1444. doi: 10.1002/humu.21238

Strehle, E.M., Yu, L., Rosenfeld, J.A., Donkervoort, S., Zhou, Y., . . Huang, T. (2012). Genotype-phenotype analysis of 4q deletion syndrome: proposal of a critical region. American Journal of Medical Genetics Part A, 158, 2139-2151. doi:10.1002/ajmg.a.35502

Suri, S., Ross, R.B., \& Tompson, B.D. (2006). Mandibular morphology and growth with and without hypodontia in subjects with Pierre Robin sequence. American Journal of Orthodontics and Dentofacial Orthopedics, 130, 37-46. doi:10.1016/j.ajodo.2005.09.026

Suri, S., Ross, R.B., \& Tompson, B.D. (2010). Craniofacial morphology and adolescent facial growth in Pierre Robin sequence. American Journal of Orthodontics and Dentofacial Orthopedics, 137, 763-774. doi:10.1016/j.ajodo.2008.07.020

Swindell, E.C., Yuan, Q., Maili, L.E., Tandon, B., Wagner, D.S., \& Hecht, J.T. (2015). Crispld 2 is required for neural crest cell migration and cell viability during zebrafish craniofacial development. Genesis, 53, 660-667. 
doi:10.1002/dvg.22897

Tamura, M., Amano, T., \& Shiroishi, T. (2014). The Hand2 gene dosage effect in developmental defects and human congenital disorders. Current Topics in Developmental Biology, 110, 129-152. doi:10.1016/B978-0-12-405943-6.00003-8

Tan, T.Y., \& Farlie, P.G. (2013). Rare syndromes of the head and face-Pierre Robin sequence. Wiley Interdisciplinary Reviews. Developmental Biology, 2, 369-377. doi:10.1002/wdev.69

Tan, T.Y., Kilpatrick, N., \& Farlie, P.G. (2013). Developmental and genetic perspectives on Pierre Robin sequence. American Journal of Medical Genetics Part C: Seminars in Medical Genetics, 163, 295-305.

doi:10.1002/ajmg.c.31374

Tang, Q., Li, L., Jin, C., Lee, J.M., \& Jung, H.S. (2015). Role of region-distinctive expression of Rac1 in regulating fibronectin arrangement during palatal shelf elevation. Cell and Tissue Research, 361, 857-868. doi:10.1007/s00441-015-2169-9

Tudela, C., Formoso, M.A., Martinez, T., Perez, R., Aparicio, M., .. . Martinez-Alvarez, C. (2002). TGF-beta3 is required for the adhesion and intercalation of medial edge epithelial cells during palate fusion. International Journal of Developmental Biology, 46, 333-336.

Van den Elzen, A.P., Semmekrot, B.A., Bongers, E.M., Huygen, P.L., \& Marres, H.A. (2001). Diagnosis and treatment of the Pierre Robin sequence: results of a retrospective clinical study and review of the literature. European Journal of Pediatrics, 160, 47-53.

Vatlach, S., Maas, C., \& Poets, C.F. (2014). Birth prevalence and initial treatment of Robin sequence in Germany: a prospective epidemiologic study. Orphanet Journal of Rare Diseases, 9, 9 . doi:10.1186/1750-1172-9-9

Wagner, T., Wirth, J., Meyer, J., Zabel, B., Held, M., . . S Scherer, G. (1994). Autosomal sex reversal and campomelic dysplasia are caused by mutations in and around the SRYrelated gene SOX9. Cell, 79, 1111-1120.

Wang, Y., Gogol-Doring, A., Hu, H., Frohler, S., Ma, Y., . . Chen, W. (2013). Integrative analysis revealed the molecular mechanism underlying RBM10-mediated splicing regulation. EMBO Molecular Medicine, 5, 1431-1442. doi:10.1002/emmm.201302663

Wolf, Z.T., Leslie, E.J., Arzi, B., Jayashankar, K., Karmi, N., . . Bannasch, D.L. (2014). A LINE-1 insertion in DLX6 is responsible for cleft palate and mandibular abnormalities in a canine model of Pierre Robin sequence. PLOS Genetics, 10, e1004257. doi:10.1371/journal.pgen.1004257

Xu, J.X., Kilpatrick, N., Baker, N.L., Penington, A., Farlie, P.G., \& Tan, T.Y. (2016). Clinical and Molecular Characterisation of Children with Pierre Robin Sequence and Additional Anomalies. Molecular Syndromology 7, 322-328. doi:10.1159/000449115

Yanagisawa, H., Clouthier, D.E., Richardson, J.A., Charite, J., \& Olson, E.N. (2003).Targeted deletion of a branchial arch-specific enhancer reveals a role of dHAND in craniofacial development. Development, 130, 1069-1078.

Yu, K., Karuppaiah, K., \& Ornitz, D.M. (2015). Mesenchymal fibroblast growth factor receptor signaling regulates palatal shelf elevation during secondary palate formation. Developmental Dynamics, 244, 1427-1438.

doi:10.1002/dvdy.24319

Yuan, Q., Chiquet, B.T., Devault, L., Warman, M.L., Nakamura, Y., . . Hecht, J.T. (2012). 
- Craniofacial abnormalities result from knock down of nonsyndromic clefting gene, crispld2, in zebrafish. Genesis, 50, 871-881. doi:10.1002/dvg.22051

Zhang, Z., Wlodarczyk, B.J., Niederreither, K., Venugopalan, S., Florez, S., . . Amendt, B.A. (2011). Fuz regulates craniofacial development through tissue specific responses to signaling factors. PLoS ONE, 6, e24608.

doi: 10.1371/journal.pone.0024608

Zechi-Ceide, R.M., Moura, P.P., Raskin, S., Richieri-Costa, A., \& Guion-Almeida, M.L. (2013). A compound heterozygote SLC26A2 mutation resulting in robin sequence, mild limbs shortness, accelerated carpal ossification, and multiple epiphysial dysplasia in two Brazilian sisters. A new intermediate phenotype between diastrophic dysplasia and recessive multiple epiphyseal dysplasia. American Journal of Medical Genetics Part A, 161, 2088-2094.

doi:10.1002/ajmg.a.36057

Zeevaert, R., Foulquier, F., Dimitrov, B., Reynders, E., Van Damme-Lombaerts, R., . . . Jaeken, J. (2009). Cerebrocostomandibular-like syndrome and a mutation in the conserved oligomeric Golgi complex, subunit 1. Human Molecular Genetics, 18, $517-$ 524. doi:10.1093/hmg/ddn379
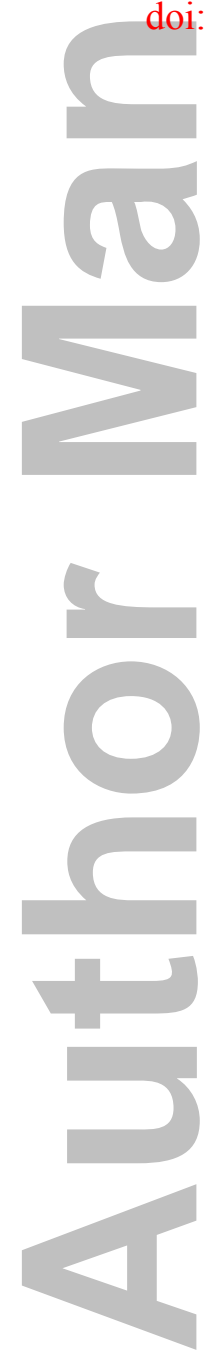


\section{FIGURE LEGENDS}

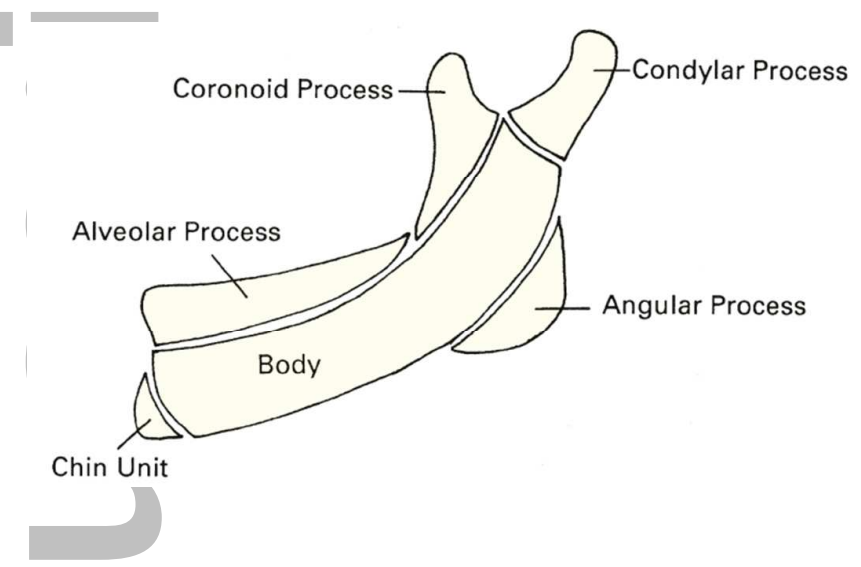

Fig 1: The mandible divided in skeletal units.

Reprinted from the textbook Craniofacial Embryogenetics and Development, 2nd edition by G.H. Sperber, S.M. Sperber and G.D. Guttmann with permission of the publisher, People's Medical Publishing House_-USA, Raleigh, North Carolina.

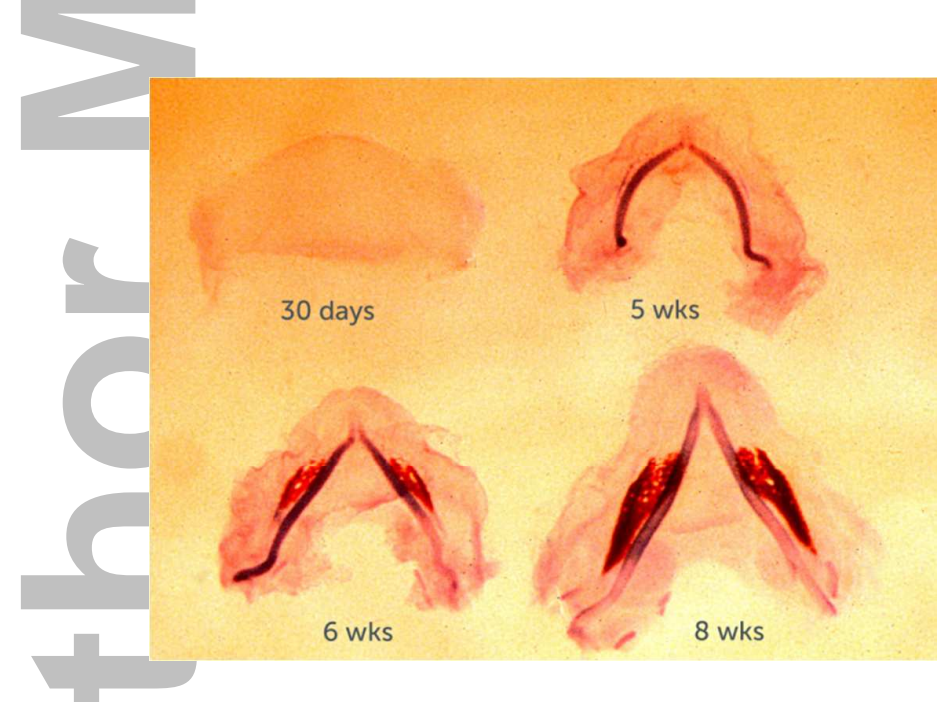

Fig 2: Intramembranous mandibular bone forming adjacent to Meckel's cartilage.

Reprinted from the textbook Craniofacial Embryogenetics and Development, 2nd edition by G.H. Sperber, S.M. Sperber and G.D. Guttmann with permission of the publisher, People's Medical Publishing House-USA, Raleigh, North Carolina. 


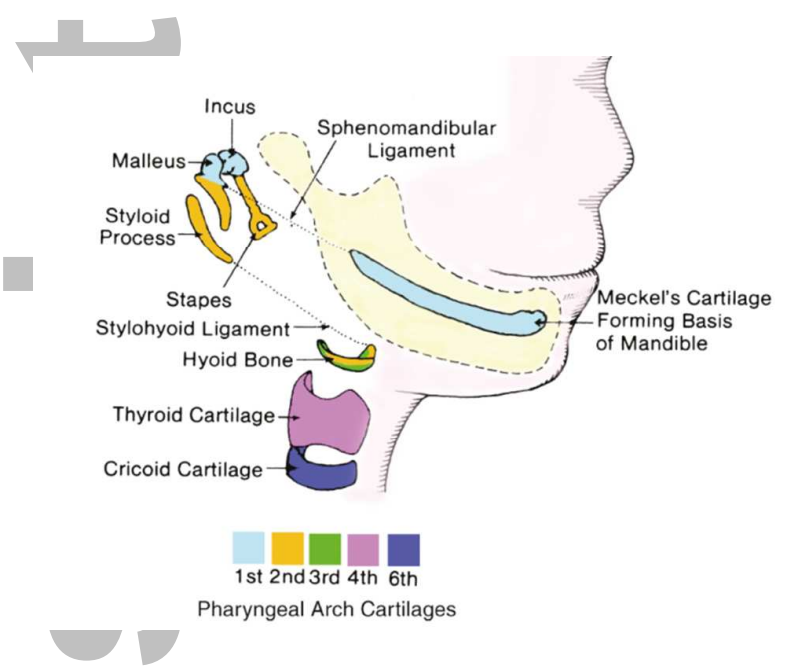

\section{Fig 3: Derivatives of the pharyngeal arch cartilages.}

Reprinted from the textbook Craniofacial Embryogenetics and Development, 2nd edition by G.H. Sperber, S.M. Sperber and G.D. Guttmann with permission of the publisher, People's Medical Publishing House-USA, Raleigh, North Carolina.

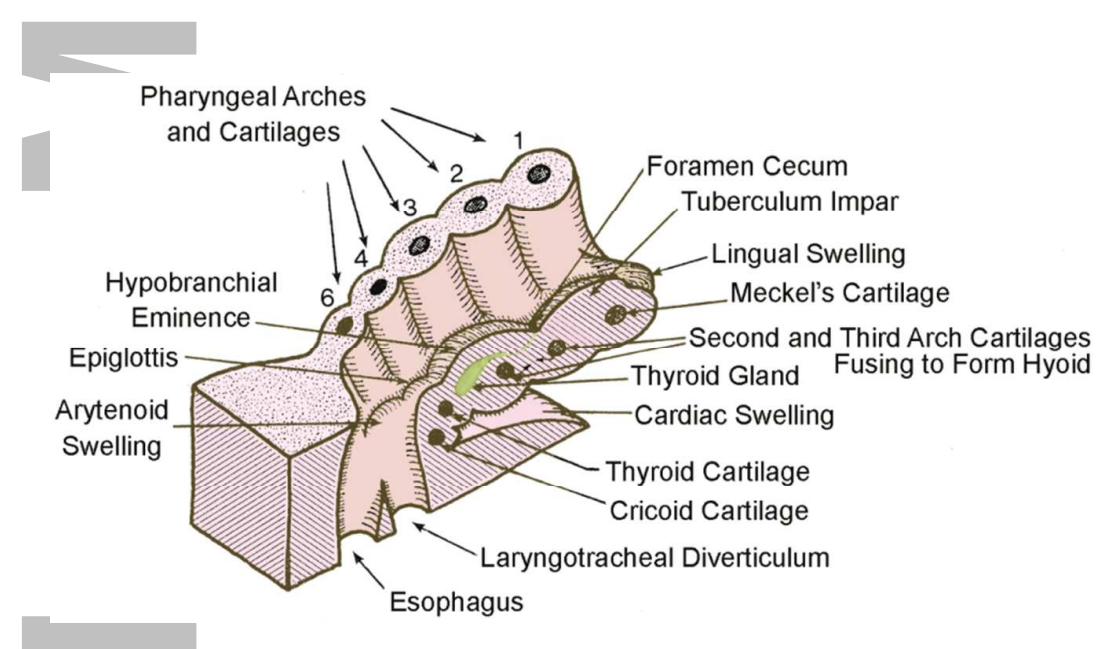

Fig 4: Tongue primordial arising in the ventral wall of the pharynx of a 4-week-old embryo.

Reprinted from the textbook Craniofacial Embryogenetics and Development, 2nd edition by G.H. Sperber, S.M. Sperber and G.D. Guttmann with permission of the publisher, People's Medical Publishing House-USA, Raleigh, North Carolina. 


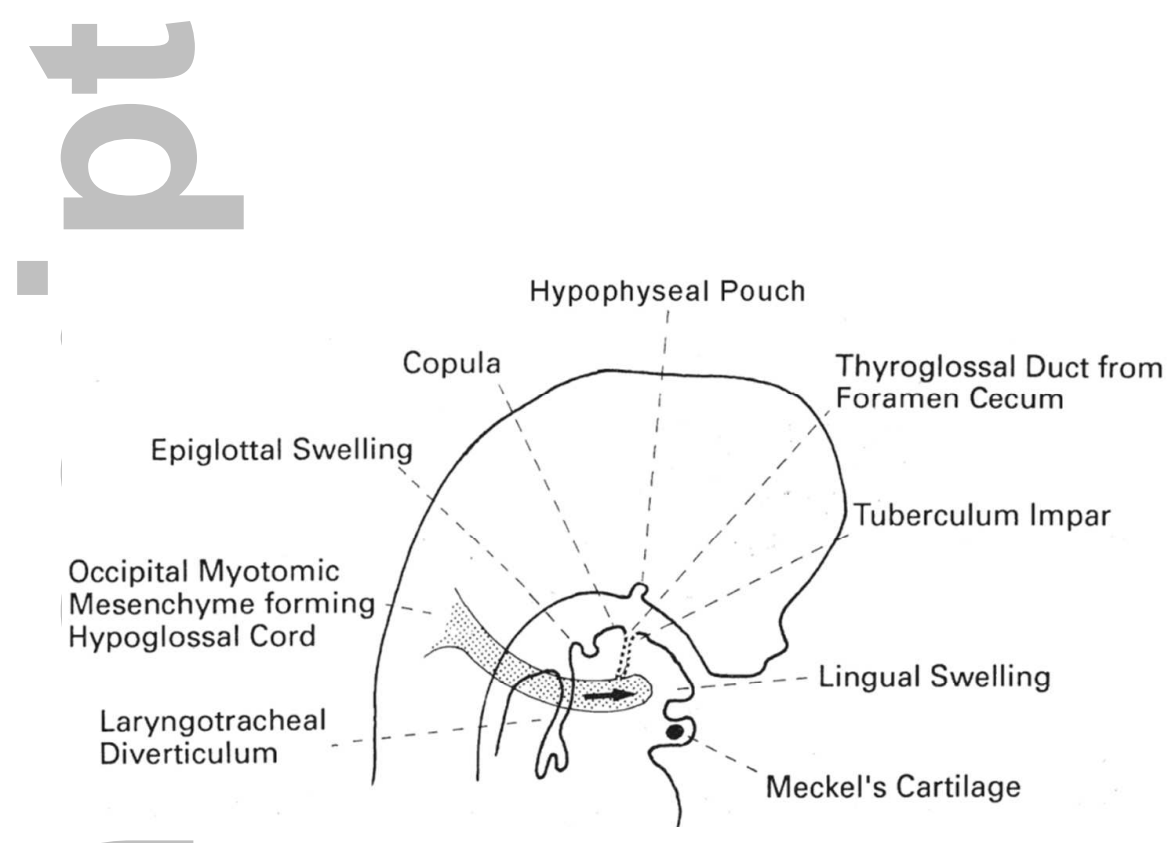

Fig 5: Paramedian section of a 5-week-old embryo illustrating the development of the ventral wall of the oropharynx and path of migration of the occipital somite myotomes forming the tongue muscles.

Reprinted from the textbook Craniofacial Embryogenetics and Development, 2nd edition by G.H. Sperber, S.M. Sperber and G.D. Guttmann with permission of the publisher, People's Medical Publishing House_-USA, Raleigh, North Carolina.

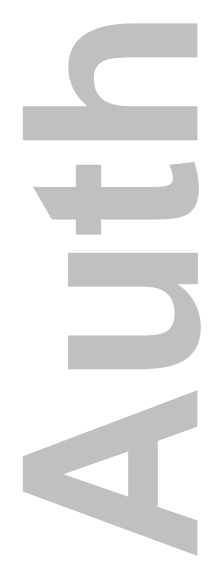




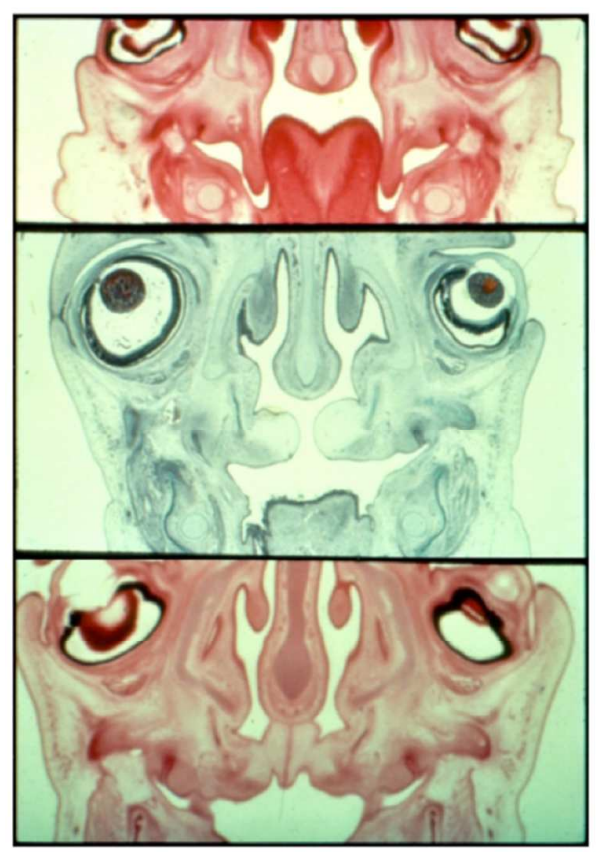

Fig 6: Stages of palatal development, elevation and fusion.

"By kind permission of Dr. Virginia Diewert"

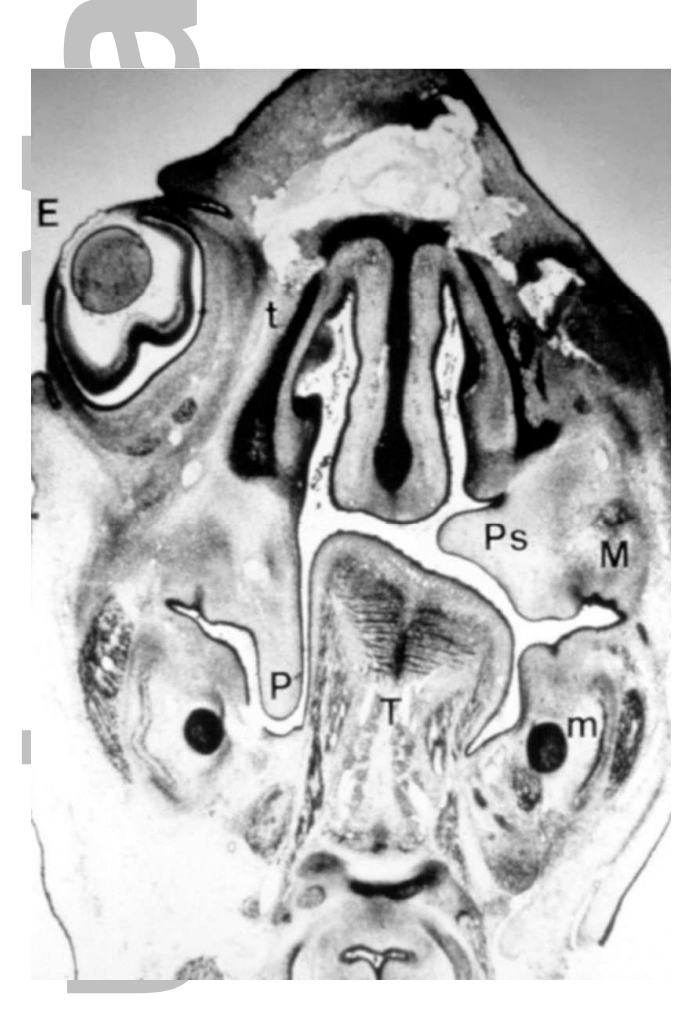

Fig 7: Tongue intervention in palatal shelf elevation. $\mathbf{E}=$ eye; $\mathbf{m}=$ mandible, $\mathbf{M}=$ maxilla, $P$ and $P s=$ Palatal shelf. 


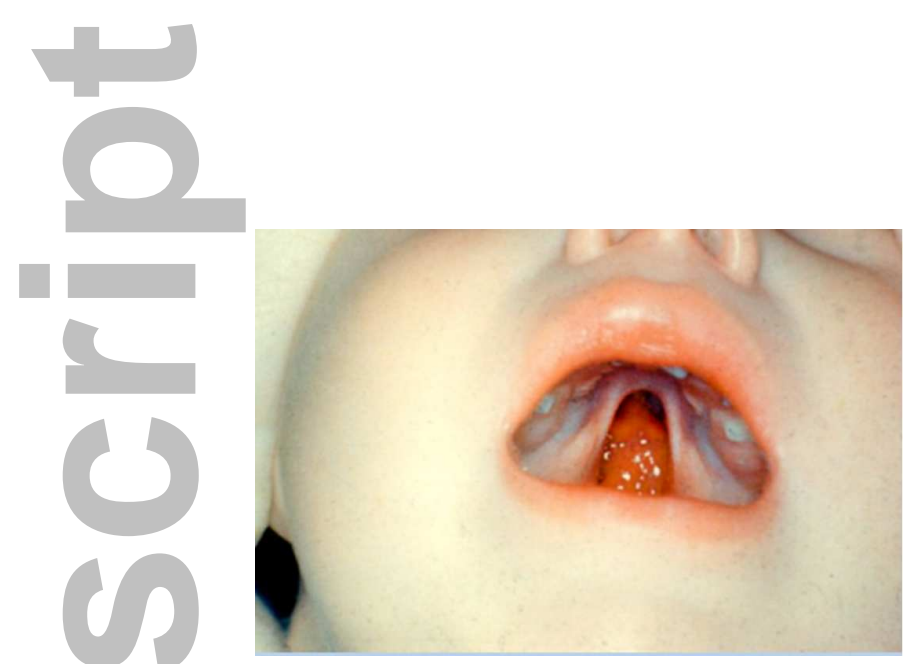

Fig 8: U-shaped cleft palate characteristic of Robin sequence.

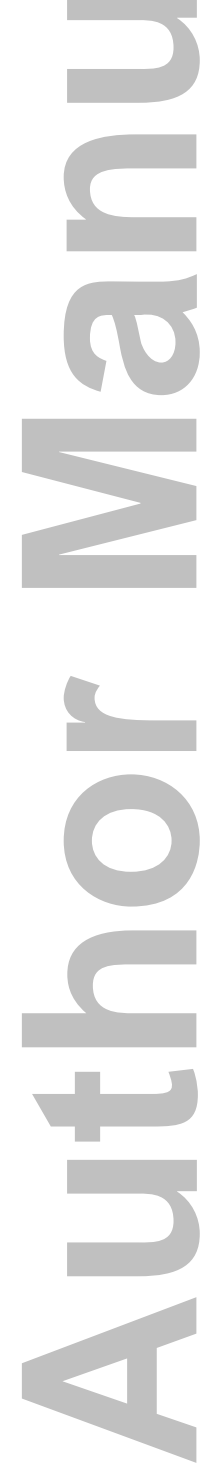

John Wiley \& Sons, Inc.

This article is protected by copyright. All rights reserved. 
TABLE 1: Identified genes, gene functions \& expressions and phenotypes associated with Robin sequence.

\begin{tabular}{|c|c|c|c|c|c|c|c|c|c|c|}
\hline & Gene & $\begin{array}{l}\text { Gene } \\
\text { MIM }\end{array}$ & $\begin{array}{c}\text { Chromosome } \\
\text { location }\end{array}$ & Inheritance & $\begin{array}{c}\text { Gene } \\
\text { function }\end{array}$ & Gene expression & Condition & $\begin{array}{l}\text { Phenotype } \\
\text { MIM }\end{array}$ & Synonym & Main features \\
\hline \multicolumn{11}{|l|}{$\begin{array}{l}\text { Collagen or } \\
\text { bone } \\
\text { development }\end{array}$} \\
\hline & TGDS & 616146 & $13 q 32.1$ & $\mathrm{AD}$ & $\begin{array}{l}\text { Proteoglycan } \\
\text { synthesis or } \\
\text { sulfation }\end{array}$ & Cartilage & Catel-Manzke syndrome & 616145 & $\begin{array}{l}\text { PIERRE ROBIN } \\
\text { SYNDROME WITH } \\
\text { HYPERPHALANGY AND } \\
\text { CLINODACTYLY }\end{array}$ & $\begin{array}{l}\text { Robin Sequence with } \\
\text { hyperphalangy } \\
\text { and clinodactyly. }\end{array}$ \\
\hline & COL11A1 & 120280 & $1 \mathrm{p} 21.1$ & $\mathrm{AD}$ & $\begin{array}{l}\text { Fibril- } \\
\text { forming } \\
\text { collagen }\end{array}$ & $\begin{array}{l}\text { Mainly in cartilage } \\
\text { extracellular matrix. }\end{array}$ & Marshall syndrome & 154780 & MARSHALL SYNDROME & $\begin{array}{l}\text { Chondrodysplasia, midfacial } \\
\text { hypoplasia, high myopia, and } \\
\text { sensorineural hearingloss. }\end{array}$ \\
\hline & COL11A1 & 120280 & $1 \mathrm{p} 21.1$ & $\mathrm{AD}$ & $\begin{array}{l}\text { Fibril- } \\
\text { forming } \\
\text { collagen }\end{array}$ & $\begin{array}{l}\text { Mainly in cartilage } \\
\text { extracellular matrix. }\end{array}$ & Stickler syndrome, type II & 604841 & $\begin{array}{l}\text { STICKLER SYNDROME, } \\
\text { VITREOUS TYPE } 2\end{array}$ & $\begin{array}{l}\text { Stickler syndrome with } \\
\text { congenital nonprogressive } \\
\text { myopia of a high degree and } \\
\text { abnormal vitreous architecture. }\end{array}$ \\
\hline & COL11A2 & 120290 & $6 \mathrm{p} 21.32$ & $\mathrm{AD}$ & $\begin{array}{l}\text { Fibril- } \\
\text { forming } \\
\text { collagen }\end{array}$ & $\begin{array}{l}\text { Mainly in cartilage } \\
\text { extracellular matrix. }\end{array}$ & $\begin{array}{l}\text { Weissenbacher- } \\
\text { Zweymuller syndrome }\end{array}$ & 277610 & $\begin{array}{l}\text { PIERRE ROBIN } \\
\text { SYNDROME WITH } \\
\text { FETAL } \\
\text { CHONDRODYSPLASIA }\end{array}$ & $\begin{array}{l}\text { Neonatal micrognathia and } \\
\text { rhizomelic chondrodysplasia with } \\
\text { dumbbell-shaped femora and } \\
\text { humeri, and regression of bone } \\
\text { changes and normal growth in } \\
\text { later years, myopia. }\end{array}$ \\
\hline & COL11A2 & 120290 & $6 \mathrm{p} 21.32$ & $\mathrm{AD}$ & $\begin{array}{l}\text { Fibril- } \\
\text { forming } \\
\text { collagen }\end{array}$ & $\begin{array}{l}\text { Mainly in cartilage } \\
\text { extracellular matrix. }\end{array}$ & Stickler syndrome, type III & 184840 & $\begin{array}{l}\text { STICKLER SYNDROME, } \\
\text { NONOCULAR TYPE }\end{array}$ & $\begin{array}{l}\text { Stickler syndrome without ocular } \\
\text { phenotype. }\end{array}$ \\
\hline & COL11A2 & 120290 & $6 \mathrm{p} 21.32$ & $\mathrm{AD}$ & $\begin{array}{l}\text { Fibril- } \\
\text { forming } \\
\text { collagen }\end{array}$ & $\begin{array}{l}\text { Mainly in cartilage } \\
\text { extracellular matrix. }\end{array}$ & $\begin{array}{l}\text { Oto- } \\
\text { spondylomegaepiphyseal } \\
\text { dysplasia }\end{array}$ & 215150 & $\begin{array}{l}\text { CHONDRODYSTROPHY } \\
\text { WITH SENSORINEURAL } \\
\text { DEAFNESS }\end{array}$ & $\begin{array}{l}\text { Sensorineural hearing loss, } \\
\text { enlarged epiphyses, } \\
\text { disproportionate shortness of the } \\
\text { limbs, abnormalities in vertebral } \\
\text { bodies, and typical facial features. }\end{array}$ \\
\hline & COL2A1 & 120140 & $12 \mathrm{q} 13.11$ & $\mathrm{AD}$ & $\begin{array}{l}\text { Fibril- } \\
\text { forming } \\
\text { collagen }\end{array}$ & $\begin{array}{l}\text { Mainly in the cartilage } \\
\text { extracellular matrix. }\end{array}$ & Kniest dysplasia & 156550 & KNIEST DYSPLASIA & $\begin{array}{l}\text { Short stature, round face with } \\
\text { central depression, prominent } \\
\text { eyes, enlargement and stiffness of } \\
\text { joints, contractures of fingers, } \\
\text { normal head circumference, bell- } \\
\text { shaped chest, and myopia. }\end{array}$ \\
\hline & COL2AI & 120140 & $12 \mathrm{q} 13.11$ & $\mathrm{AD}$ & $\begin{array}{l}\text { Fibril- } \\
\text { forming } \\
\text { collagen }\end{array}$ & $\begin{array}{l}\text { Mainly in the cartilage } \\
\text { extracellular matrix. }\end{array}$ & Stickler syndrome, type I & 108300 & $\begin{array}{l}\text { STICKLER SYNDROME, } \\
\text { TYPE I }\end{array}$ & $\begin{array}{l}\text { Characterized by ocular, auditory, } \\
\text { skeletal, and orofacial } \\
\text { abnormalities. }\end{array}$ \\
\hline
\end{tabular}

John Wiley \& Sons, Inc.

This article is protected by copyright. All rights reserved. 


\begin{tabular}{|c|c|c|c|c|c|c|c|c|c|c|}
\hline & & & & & $\begin{array}{l}\text { complex. Key } \\
\text { determinants } \\
\text { of Golgi } \\
\text { apparatus } \\
\text { structure and } \\
\text { its capacity } \\
\text { for } \\
\text { intracellular } \\
\text { transport and } \\
\text { glycoprotein } \\
\text { modification. }\end{array}$ & & & & & \\
\hline & $P G M 1$ & 171900 & $1 \mathrm{p} 31.3$ & $\mathrm{AR}$ & $\begin{array}{l}\text { Enzyme } \\
\text { participating } \\
\text { in both the } \\
\text { breakdown } \\
\text { and synthesis } \\
\text { of glucose. }\end{array}$ & $\begin{array}{l}\text { Trophoblast, neuron, } \\
\text { skeletal muscle, bone, } \\
\text { testis, liver, eye. }\end{array}$ & $\begin{array}{l}\text { Congenital disorder of } \\
\text { glycosylation, type It }\end{array}$ & 614921 & $\begin{array}{l}\text { PHOSPHOGLUCOMUTAS } \\
\text { ES (PGM1) }\end{array}$ & $\begin{array}{l}\text { Cleft lip and bifid uvula, } \\
\text { hepatopathy, intermittent } \\
\text { hypoglycemia, short stature, } \\
\text { hypotonia, mental retardation, } \\
\text { exercise intolerance, coagulation } \\
\text { disorders, and immunodeficiency } \\
\text { Less common features include } \\
\text { rhabdomyolysis, dilated } \\
\text { cardiomyopathy, and } \\
\text { hypogonadotropic hypogonadism. }\end{array}$ \\
\hline \multicolumn{11}{|l|}{$\begin{array}{l}\text { Neuromuscul } \\
\text { ar } \\
\text { Disorder }\end{array}$} \\
\hline 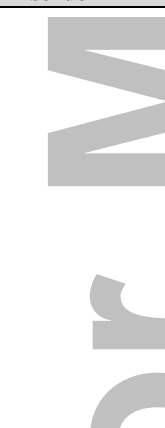 & $D M P K$ & 605377 & $19 \mathrm{q} 13.32$ & $\mathrm{AD}$ & $\begin{array}{l}\text { Non-receptor } \\
\text { serine/threoni } \\
\text { ne protein } \\
\text { kinase } \\
\text { necessary for } \\
\text { the } \\
\text { maintenance } \\
\text { of skeletal } \\
\text { muscle } \\
\text { structure and } \\
\text { function; May } \\
\text { play a role in } \\
\text { myocyte } \\
\text { differentiation } \\
\text { and survival. }\end{array}$ & $\begin{array}{l}\text { Expressed in many } \\
\text { tissues including heart, } \\
\text { skeletal muscle, liver } \\
\text { and brain. }\end{array}$ & $\begin{array}{l}\text { Congenital Myotonic } \\
\text { Dystrophy }\end{array}$ & 160900 & STEINERT DISEASE & $\begin{array}{l}\text { Hypotonia and severe generalized } \\
\text { weakness at birth, often with } \\
\text { respiratory insufficiency and } \\
\text { early death; intellectual disability } \\
\text { is common. }\end{array}$ \\
\hline & Unknown & Unknown & Unknown & $\begin{array}{l}\mathrm{AR} \\
\text { (probably) }\end{array}$ & Unknown & Unknown & $\begin{array}{l}\text { Carey-Fineman-Ziter } \\
\text { syndrome }\end{array}$ & 254940 & $\begin{array}{l}\text { MYOPATHY, } \\
\text { CONGENITAL } \\
\text { NONPROGRESSIVE, } \\
\text { WITH MOEBIUS } \\
\text { SEQUENCE AND ROBIN } \\
\text { SEQUENCE }\end{array}$ & $\begin{array}{l}\text { Craniofacial anomalies, } \\
\text { micrognathia, Moebius sequence, } \\
\text { generalized myopathy, relative } \\
\text { macrocephaly, and } \\
\text { developmental delay. Additional } \\
\text { features scoliosis, talipes } \\
\text { equinovarus, and a nonspecific } \\
\text { primary myopathy as important }\end{array}$ \\
\hline
\end{tabular}

John Wiley \& Sons, Inc. 


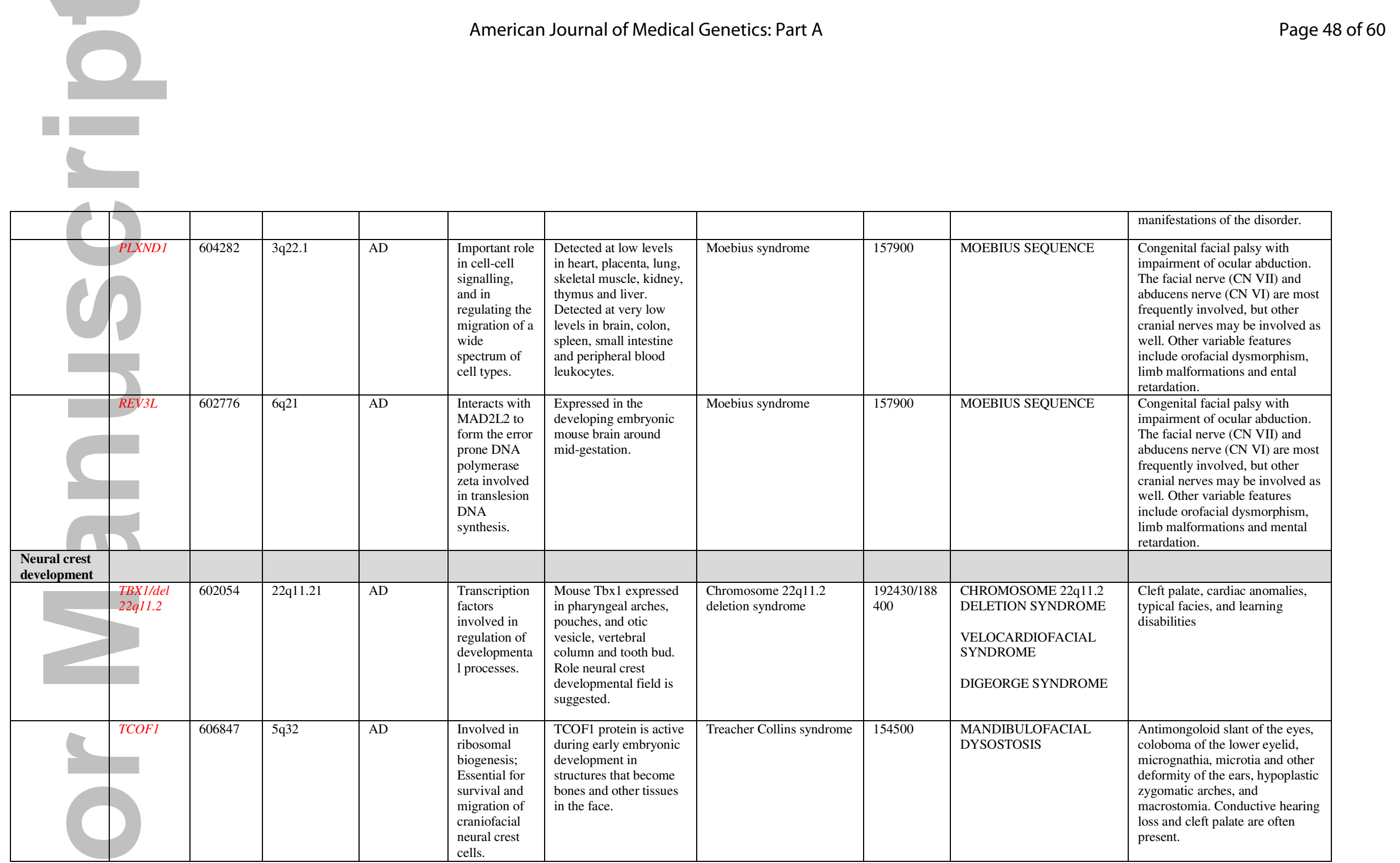

John Wiley \& Sons, Inc. 


\begin{tabular}{|c|c|c|c|c|c|c|c|c|c|c|}
\hline & POLRID & 613715 & $13 \mathrm{q} 12.2$ & $\mathrm{AD}$ & $\begin{array}{l}\text { Encode RNA } \\
\text { polymerases I } \\
\text { and III } \\
\text { involved in } \\
\text { ribosome } \\
\text { biosynthesis. }\end{array}$ & $\begin{array}{l}\text { POLR1C plays a role in } \\
\text { expression of TCOF1 }\end{array}$ & $\begin{array}{l}\text { Treacher Collins syndrome } \\
2\end{array}$ & 613717 & $\begin{array}{l}\text { TREACHER COLLINS } \\
\text { SYNDROME } 2\end{array}$ & $\begin{array}{l}\text { Antimongoloid slant of the eyes, } \\
\text { coloboma of the lower eyelid, } \\
\text { micrognathia, microtia and other } \\
\text { deformity of the ears, hypoplastic } \\
\text { zygomatic arches, and } \\
\text { macrostomia. Conductive hearing } \\
\text { loss and cleft palate are often } \\
\text { present. }\end{array}$ \\
\hline & POLRIC & 610060 & $6 \mathrm{p} 21.1$ & $\mathrm{AD}$ & $\begin{array}{l}\text { Involved in } \\
\text { ribosome } \\
\text { biosynthesis. }\end{array}$ & $\begin{array}{l}\text { POLR1D plays a role in } \\
\text { expression of TCOF1 }\end{array}$ & $\begin{array}{l}\text { Treacher Collins syndrome } \\
3\end{array}$ & 248390 & $\begin{array}{l}\text { MANDIBULOFACIAL } \\
\text { DYSOSTOSIS, } \\
\text { TREACHER COLLINS } \\
\text { TYPE, AUTOSOMAL } \\
\text { RECESSIVE }\end{array}$ & $\begin{array}{l}\text { Antimongoloid slant of the eyes, } \\
\text { coloboma of the lower eyelid, } \\
\text { micrognathia, microtia and other } \\
\text { deformity of the ears, hypoplastic } \\
\text { zygomatic arches, and } \\
\text { macrostomia. Conductive hearing } \\
\text { loss and cleft palate are often } \\
\text { present. }\end{array}$ \\
\hline & DHODH & 126064 & $16 q 22.2$ & $\mathrm{AR}$ & $\begin{array}{l}\text { Catalyses the } \\
\text { fourth } \\
\text { enzymatic } \\
\text { step in de } \\
\text { novo } \\
\text { pyrimidine } \\
\text { biosynthesis. }\end{array}$ & Neural crest cells & Miller syndrome & 263750 & $\begin{array}{l}\text { POSTAXIAL } \\
\text { ACROFACIAL } \\
\text { DYSOSTOSIS }\end{array}$ & $\begin{array}{l}\text { Micrognathia, cleft lip and/or } \\
\text { palate, hypoplasia or aplasia of } \\
\text { the postaxial elements of the } \\
\text { limbs, coloboma of the eyelids, } \\
\text { and supernumerary nipples . }\end{array}$ \\
\hline \multicolumn{11}{|l|}{$\begin{array}{l}\text { Pharyngeal } \\
\text { arches } \\
\text { development }\end{array}$} \\
\hline & GNAI3 & 139370 & $1 \mathrm{p} 13.3$ & $\mathrm{AD}$ & $\begin{array}{l}\text { Functions } \\
\text { downstream } \\
\text { of the } \\
\text { EDNRA; } \\
\text { crucial role in } \\
\text { pharyngeal } \\
\text { arch } \\
\text { patterning. }\end{array}$ & $\begin{array}{l}\text { Mandibular domain of } \\
\text { the first arch. }\end{array}$ & $\begin{array}{l}\text { Auriculocondylar } \\
\text { syndrome } 1\end{array}$ & 602483 & $\begin{array}{l}\text { QUESTION MARK EARS } \\
\text { SYNDROME }\end{array}$ & $\begin{array}{l}\text { Malformed ears (question mark } \\
\text { ears), prominent cheeks, } \\
\text { microstomia, abnormal } \\
\text { temporomandibular joint, and } \\
\text { mandibular condyle hypoplasia. }\end{array}$ \\
\hline & & 600810 & 20p12. & $\mathrm{AR}, \mathrm{AD}$ & $\begin{array}{l}\text { Functions } \\
\text { downstream } \\
\text { of the } \\
\text { EDNRA; } \\
\text { crucial role in } \\
\text { pharyngeal } \\
\text { arch } \\
\text { patterning. }\end{array}$ & $\begin{array}{l}\text { Mandibular domain of } \\
\text { the first arch. }\end{array}$ & $\begin{array}{l}\text { Auriculocondylar } \\
\text { syndrome } 2\end{array}$ & 614669 & $\begin{array}{l}\text { AURICULOCONDYLAR } \\
\text { SYNDROME } 2\end{array}$ & $\begin{array}{l}\text { Malformed ears (question mark } \\
\text { ears), prominent cheeks, } \\
\text { microstomia, abnormal } \\
\text { temporomandibular joint, and } \\
\text { mandibular condyle hypoplasia. }\end{array}$ \\
\hline
\end{tabular}

John Wiley \& Sons, Inc. 


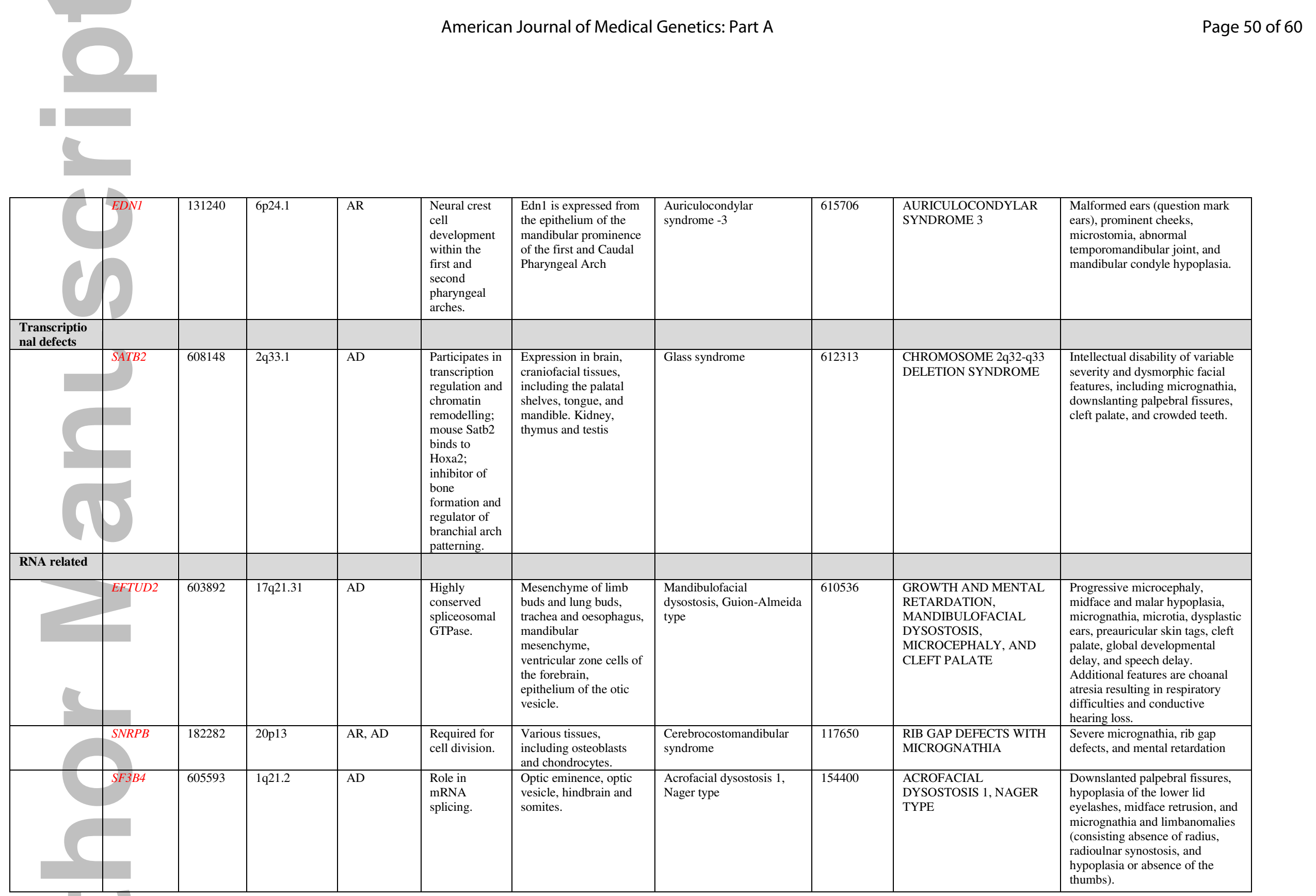

John Wiley \& Sons, Inc.

This article is protected by copyright. All rights reserved. 


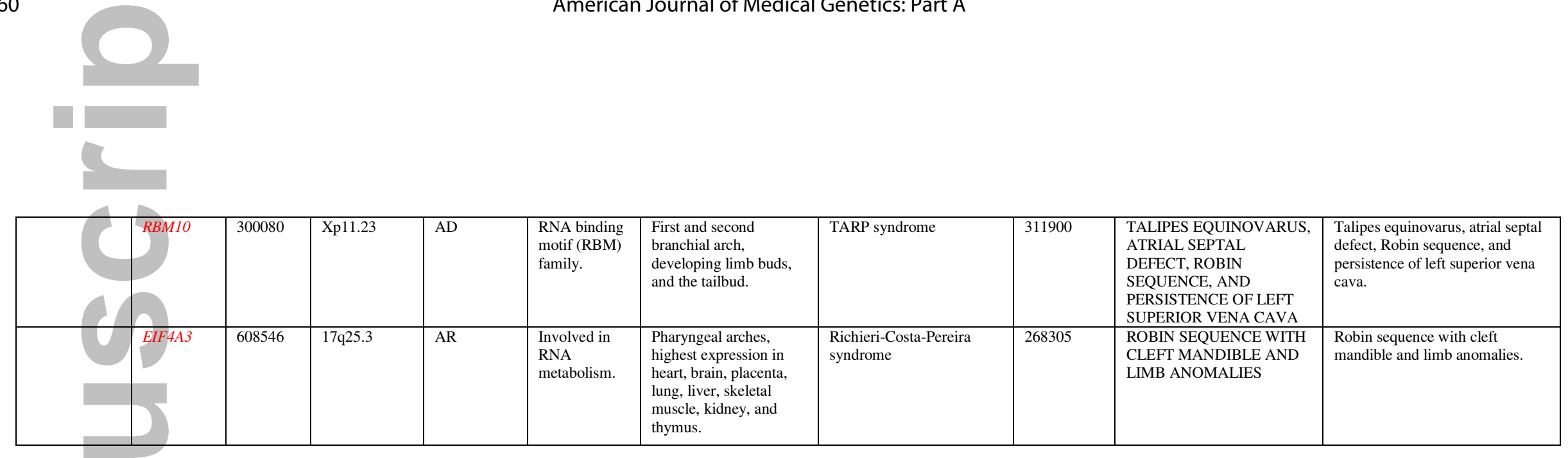

\section{TABLE 1: Identified genes, gene functions \& expressions and phenotypes associated with Robin sequence.}

\section{Legend:}

MIM: Mendelian Inheritance in Man, AD: Autosomal Dominant, AR: Autosomal Recessive, CN: Cranial nerve, RNA: Ribonucleic Acid, DNA: Deoxyribonucleic acid 
Table 2. Candidate genes associated with Robin sequence based on animal models

\begin{tabular}{|c|c|c|c|c|c|c|}
\hline Study & Gene & Gene MIM & $\begin{array}{l}\text { Chromosome } \\
\text { location }\end{array}$ & $\begin{array}{l}\text { Type of animal } \\
\text { model }\end{array}$ & Gene function & Association with Robin sequence \\
\hline $\begin{array}{l}\text { Sheehan-Rooney et al. } \\
2013\end{array}$ & HAND2 & 602407 & $4 \mathrm{q} 34.1$ & Zebrafish & $\begin{array}{l}\text { Essential for cardiac morphogenesis, required for vascular development limb } \\
\text { development and involved in the development of branchial arches }\end{array}$ & $\begin{array}{l}\text { Plays a role in appropriate expression of } \\
\text { SATB2 }\end{array}$ \\
\hline $\begin{array}{l}\text { Swindell et al. } 2015 \\
\text { Yuan et al. } 2012\end{array}$ & CRISPLD2 & 612434 & $16 q 24.1$ & Zebrafish & $\begin{array}{l}\text { Promotes matrix assembly. Binds to heparin, dermatan sulphate and } \\
\text { chondroitin sulphate }\end{array}$ & $\begin{array}{l}\text { Plays a role modulating the migration, } \\
\text { differentiation, and/or survival of neural crest } \\
\text { cells }\end{array}$ \\
\hline Ling et al. 2017 & WNT9A & 602863 & $1 \mathrm{q} 42.13$ & Zebrafish & $\begin{array}{l}\text { Probable developmental protein; May be a signalling molecule which affects } \\
\text { the development of discrete regions of tissues }\end{array}$ & $\begin{array}{l}\text { Plays a role in regulating Meckel's cartilage } \\
\text { maturation and endochondral ossification }\end{array}$ \\
\hline Zhang et al. 2011 & FUZ & 610622 & 19q13.33 & Mice & $\begin{array}{l}\text { Probable planar cell polarity effector involved in cilium biogenesis; May } \\
\text { regulate protein and membrane transport to the cilium; May regulate the } \\
\text { morphogenesis of hair follicles which depends on functional primary cilia (by } \\
\text { similarity) }\end{array}$ & $\begin{array}{l}\text { Plays a role in the negative feedback loop } \\
\text { controlling Wnt/ } \beta \text {-catenin signaling. } \\
\text { Associated with a hyperplastic malformed } \\
\text { Meckel's cartilage }\end{array}$ \\
\hline $\begin{array}{l}\text { Parada et al. } 2015 \\
\text { Koczkowska et al. } \\
2017\end{array}$ & MAPK1 & 176948 & $22 \mathrm{q} 11.22$ & Mice & $\begin{array}{l}\text { MAP kinase signaling cascade, involved in eukaryotic signal transduction: } \\
\text { transmission of extracellular signals to cytoplasmic and nuclear effectors }\end{array}$ & $\begin{array}{l}\text { Plays a role in osteogenic differentiation of } \\
\text { neural crest cells }\end{array}$ \\
\hline Duan et al. 2016 & VEGFA & 192240 & $6 \mathrm{p} 21.1$ & Mice & $\begin{array}{l}\text { Induces endothelial cell proliferation, promotes cell migration, inhibits } \\
\text { apoptosis and induces permeabilization of blood vessels }\end{array}$ & $\begin{array}{l}\text { Plays a role in optimal intramembranous } \\
\text { ossification of mandibular bones }\end{array}$ \\
\hline Ansari et al. 2014 & PHAX & 604924 & $5 \mathrm{q} 23.2$ & Mice & RNA binding & $\begin{array}{l}\text { Plays a role in the development of pharyngeal } \\
\text { arches }\end{array}$ \\
\hline Huang et al. 2016 & SOX11 & 600898 & $2 \mathrm{p} 25.2$ & Mice & $\begin{array}{l}\text { Multiple developmental processes, including regulatory network for } \\
\text { corticospinal neurons }\end{array}$ & $\begin{array}{l}\text { Plays a role in cell proliferation of developing } \\
\text { mandibular mesenchyme via Cyclin D1 }\end{array}$ \\
\hline Kouskoura et al. 2016 & $B M P 7$ & 112267 & $20 \mathrm{q} 13.31$ & Mice & $\begin{array}{l}\text { Part of the transforming growth factor-beta superfamily of regulatory } \\
\text { molecules and induces osteogenic transformation in osteoblastic cells }\end{array}$ & $\begin{array}{l}\text { Plays a role in chondrogenesis in Meckel's } \\
\text { cartilage and rostral process formation, that } \\
\text { could result in disturbances in the attachment } \\
\text { sites and the morphology of the genioglossus } \\
\text { muscle }\end{array}$ \\
\hline
\end{tabular}

Legend: NSDTR: Nova Scotia Duck Tolling Retriever, MIM: Mendelian Inheritance in Man.

* The involvement of FAF1 in Robin sequence is uncertain. Rainger et al. reported that in the single family described by Ghassibe-Sabbagh et al., while one of the translocation breakpoints fell in FAF1, the other one fell upstream of SATB2

John Wiley \& Sons, Inc.

This article is protected by copyright. All rights reserved. 


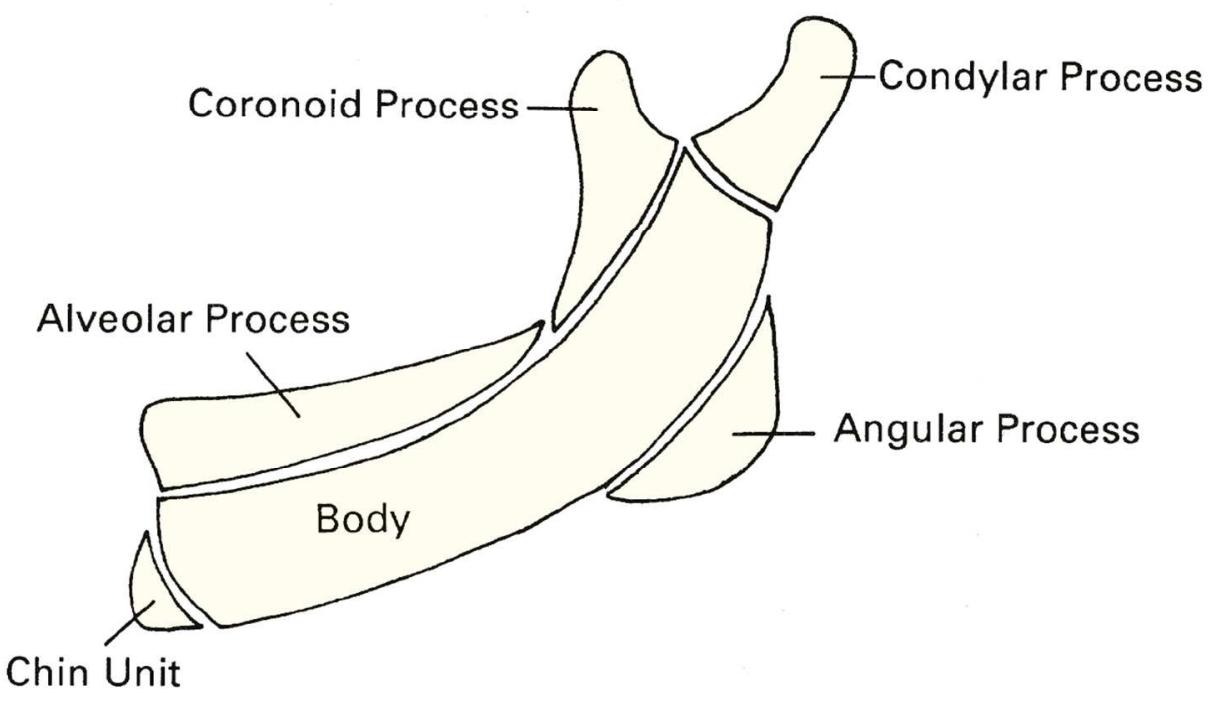

Fig 1: The mandible divided in skeletal units.

Reprinted from the textbook Craniofacial Embryogenetics and Development, 2nd edition by G.H. Sperber, S.M. Sperber and G.D. Guttmann with permission of the publisher, People's Medical Publishing House-USA, Raleigh, North Carolina.

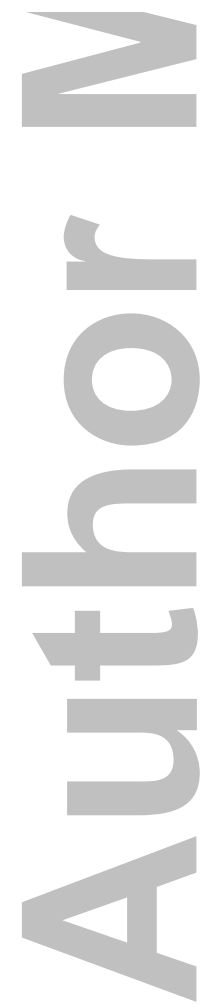

$118 \times 64 \mathrm{~mm}(300 \times 300 \mathrm{DPI})$ 


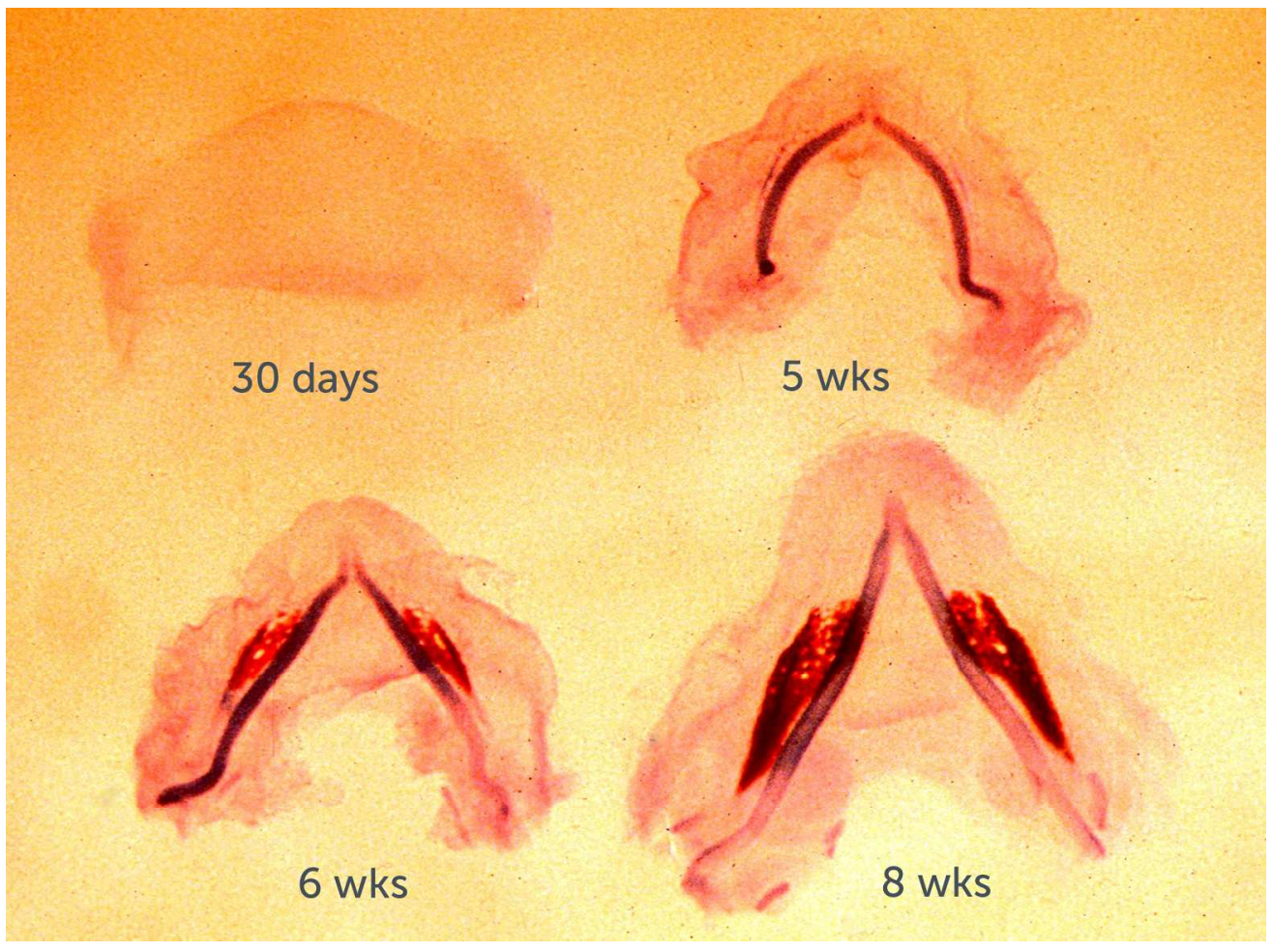

Fig 2: Intramembranous mandibular bone forming adjacent to Meckel's cartilage.

Reprinted from the textbook Craniofacial Embryogenetics and Development, 2nd edition by G.H. Sperber, S.M. Sperber and G.D. Guttmann with permission of the publisher, People's Medical Publishing House-USA, Raleigh, North Carolina.

$190 \times 140 \mathrm{~mm}(300 \times 300 \mathrm{DPI})$

John Wiley \& Sons, Inc.

This article is protected by copyright. All rights reserved. 

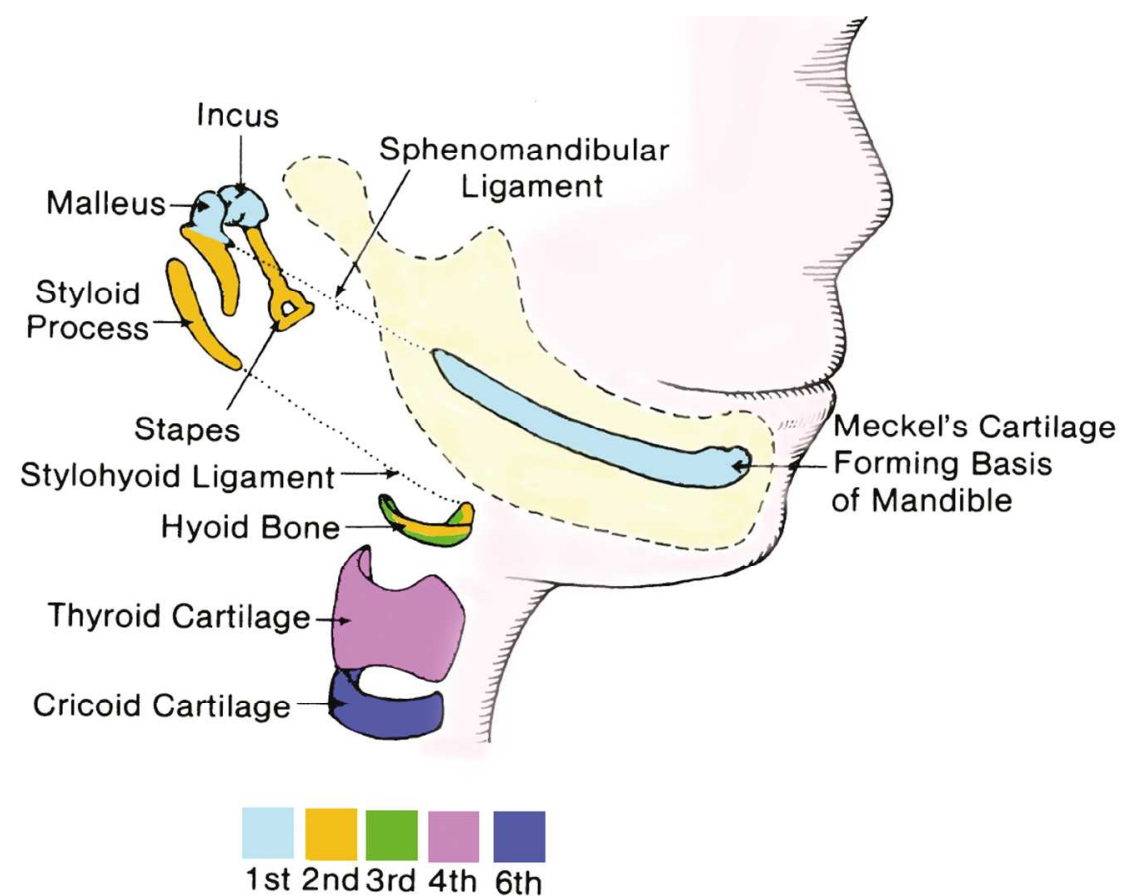

Pharyngeal Arch Cartilages

Fig 3: Derivatives of the pharyngeal arch cartilages.

Reprinted from the textbook Craniofacial Embryogenetics and Development, 2nd edition by G.H. Sperber, S.M. Sperber and G.D. Guttmann with permission of the publisher, People's Medical Publishing House-USA, Raleigh, North Carolina.

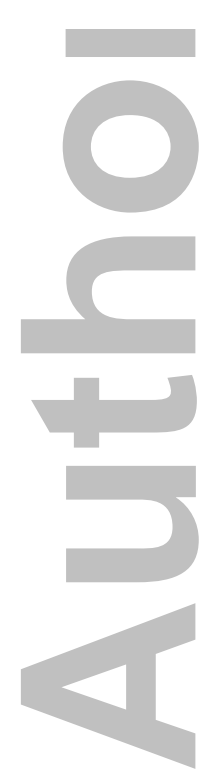

$114 \times 84 \mathrm{~mm}(300 \times 300$ DPI $)$ 


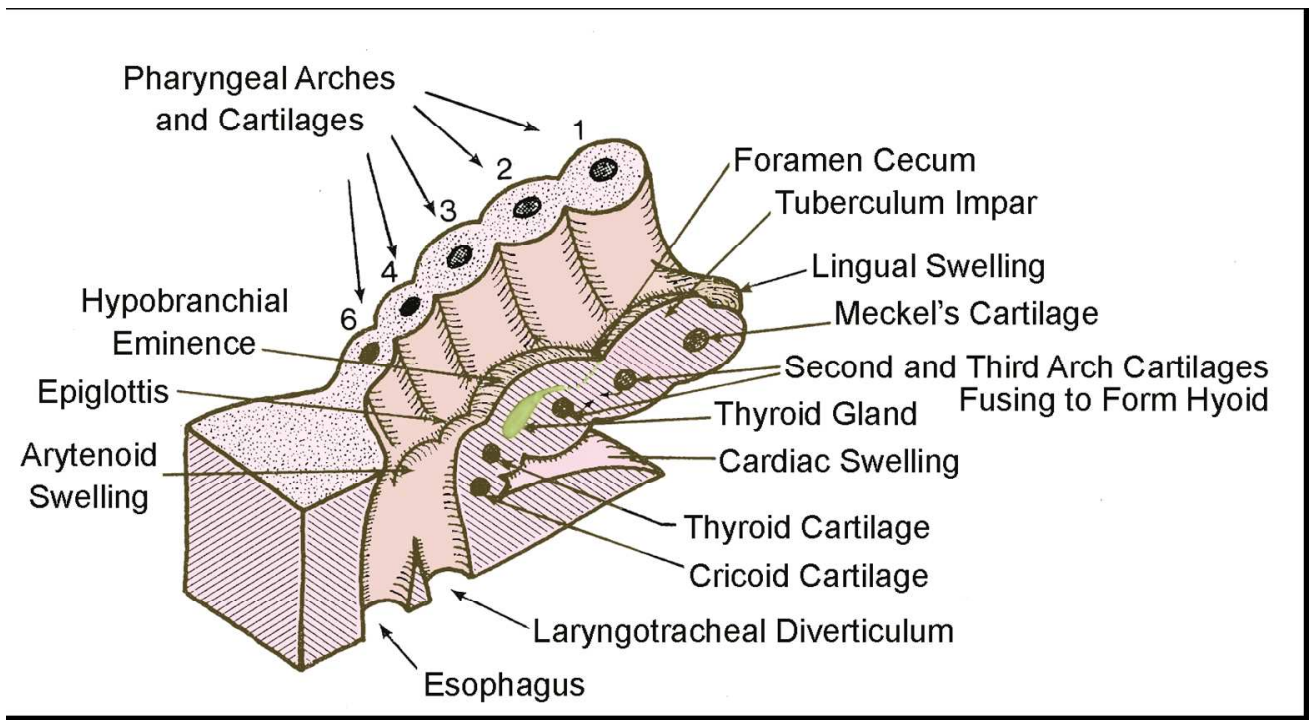

Fig 4: Tongue primordial arising in the ventral wall of the pharynx of a 4-week-old embryo.

Reprinted from the textbook Craniofacial Embryogenetics and Development, 2nd edition by G.H. Sperber, S.M. Sperber and G.D. Guttmann with permission of the publisher, People's Medical Publishing House-USA, Raleigh, North Carolina.

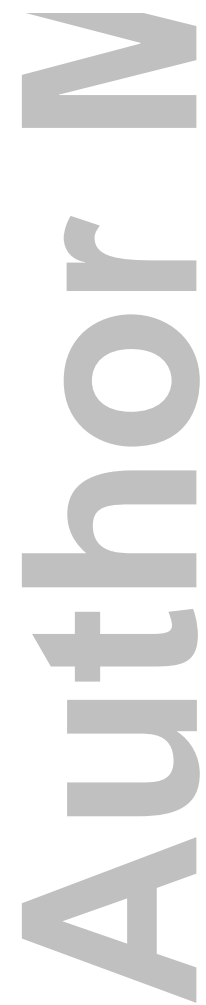

$141 \times 77 \mathrm{~mm}(300 \times 300$ DPI $)$ 


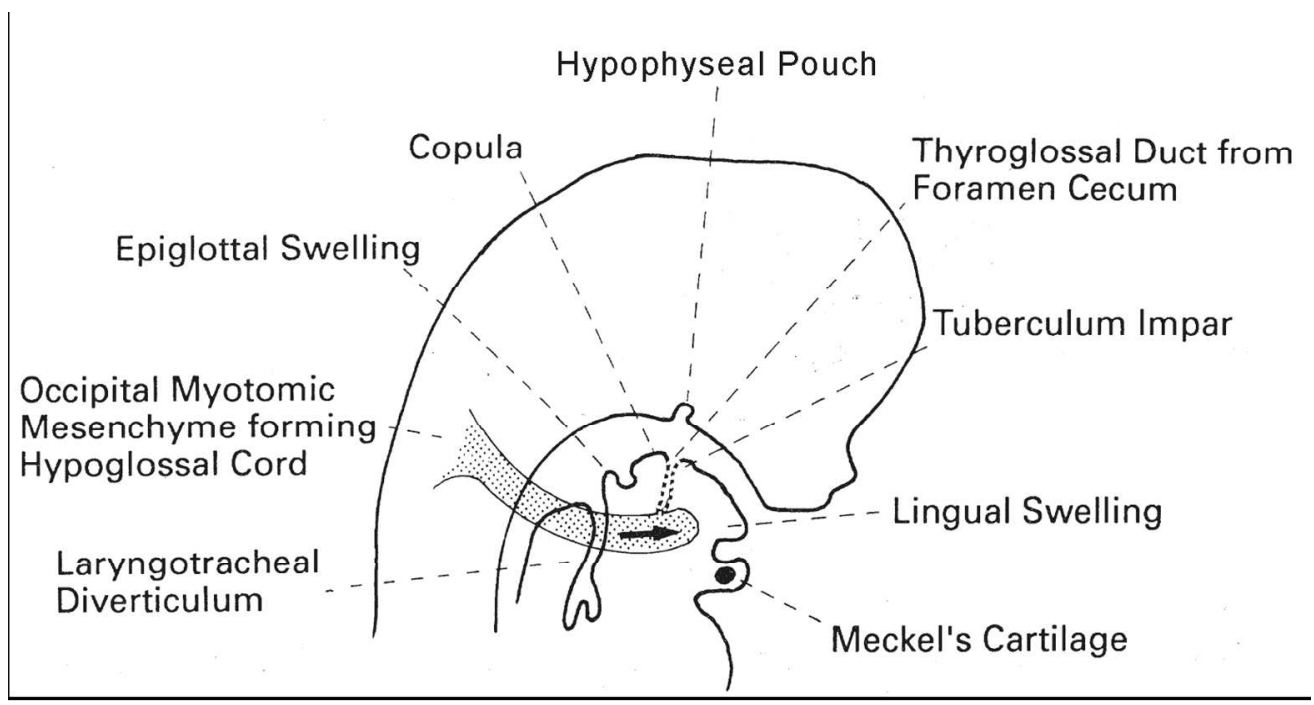

Fig 5: Paramedian section of a 5-week-old embryo illustrating the development of the ventral wall of the oropharynx and path of migration of the occipital somite myotomes forming the tongue muscles.

Reprinted from the textbook Craniofacial Embryogenetics and Development, 2nd edition by G.H. Sperber, S.M. Sperber and G.D. Guttmann with permission of the publisher, People's Medical Publishing House-USA, Raleigh, North Carolina.

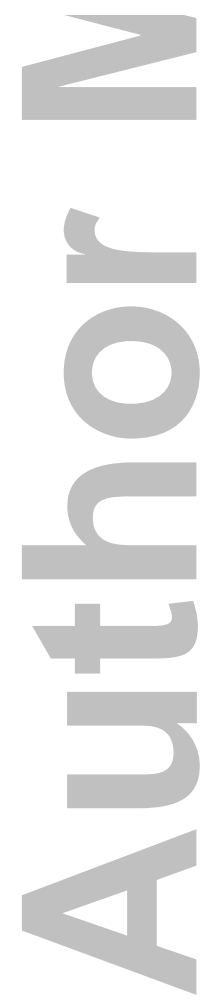

$138 \times 73 \mathrm{~mm}(300 \times 300$ DPI $)$ 


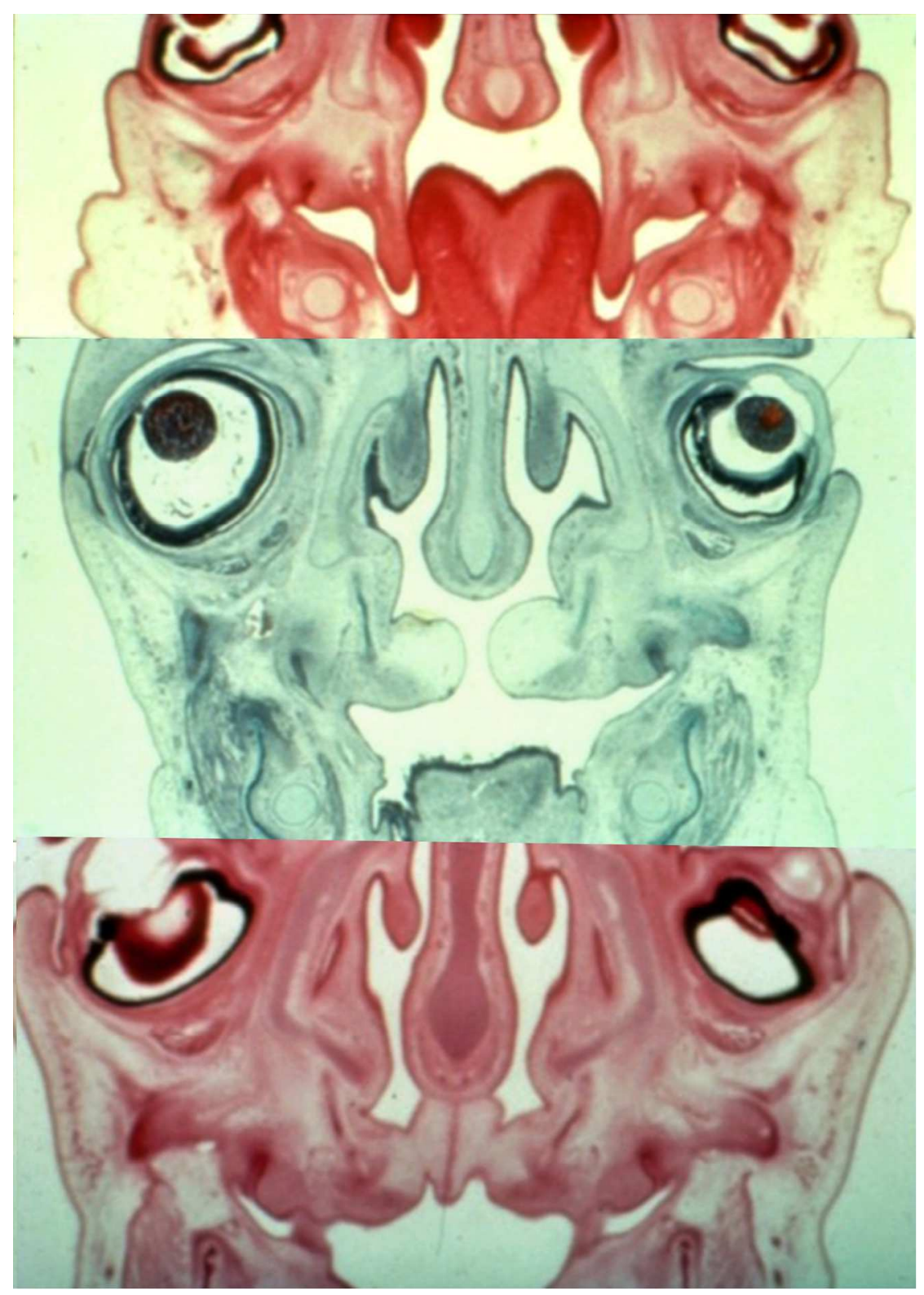

Fig 6: Stages of palatal development, elevation and fusion. "By kind permission of Dr. Virginia Diewert"

$127 \times 179 \mathrm{~mm}(300 \times 300 \mathrm{DPI})$

John Wiley \& Sons, Inc. 


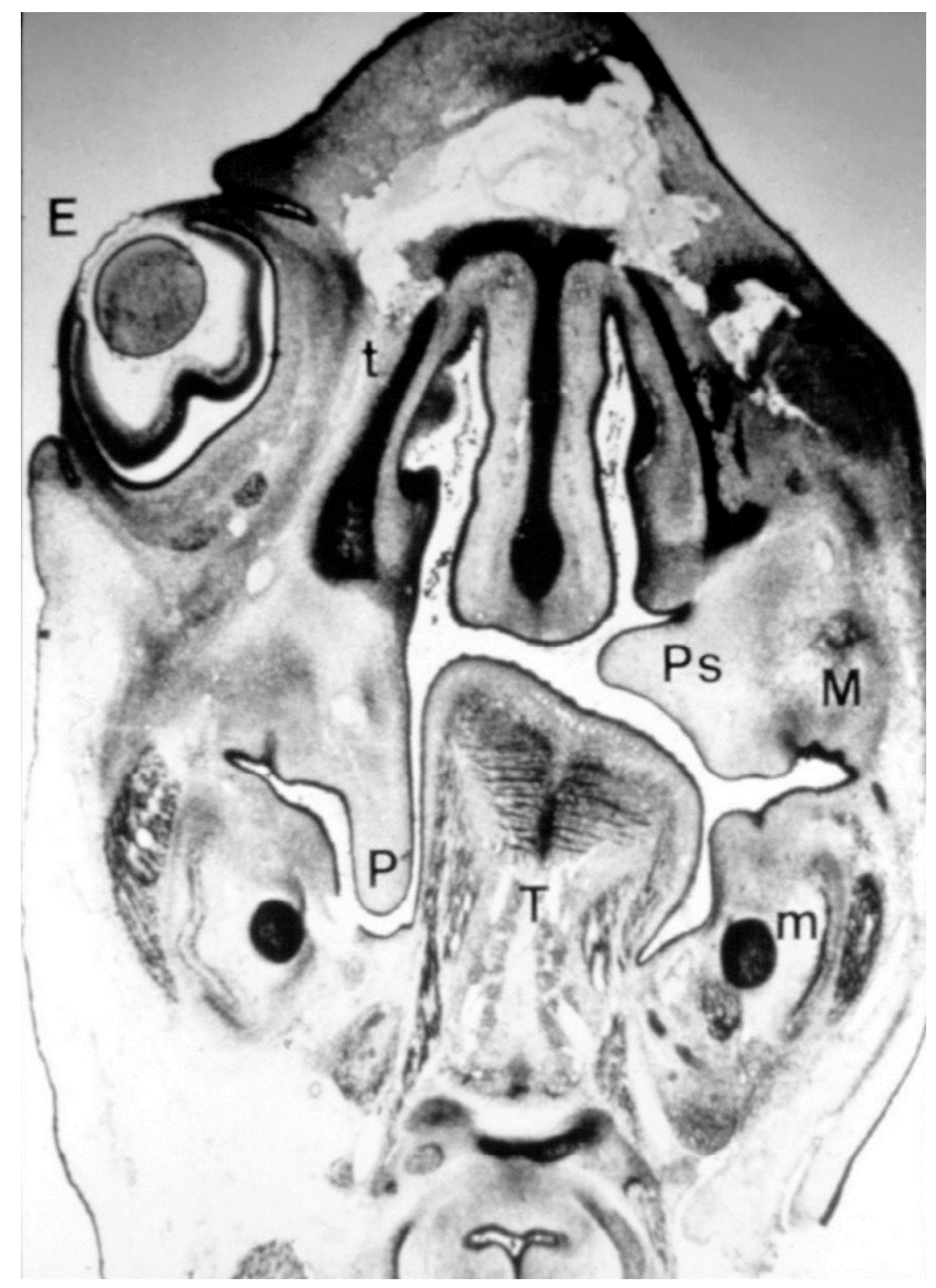

Fig 7: Tongue intervention in palatal shelf elevation. $131 \times 183 \mathrm{~mm}(300 \times 300$ DPI)

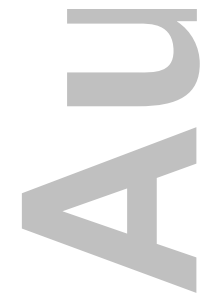




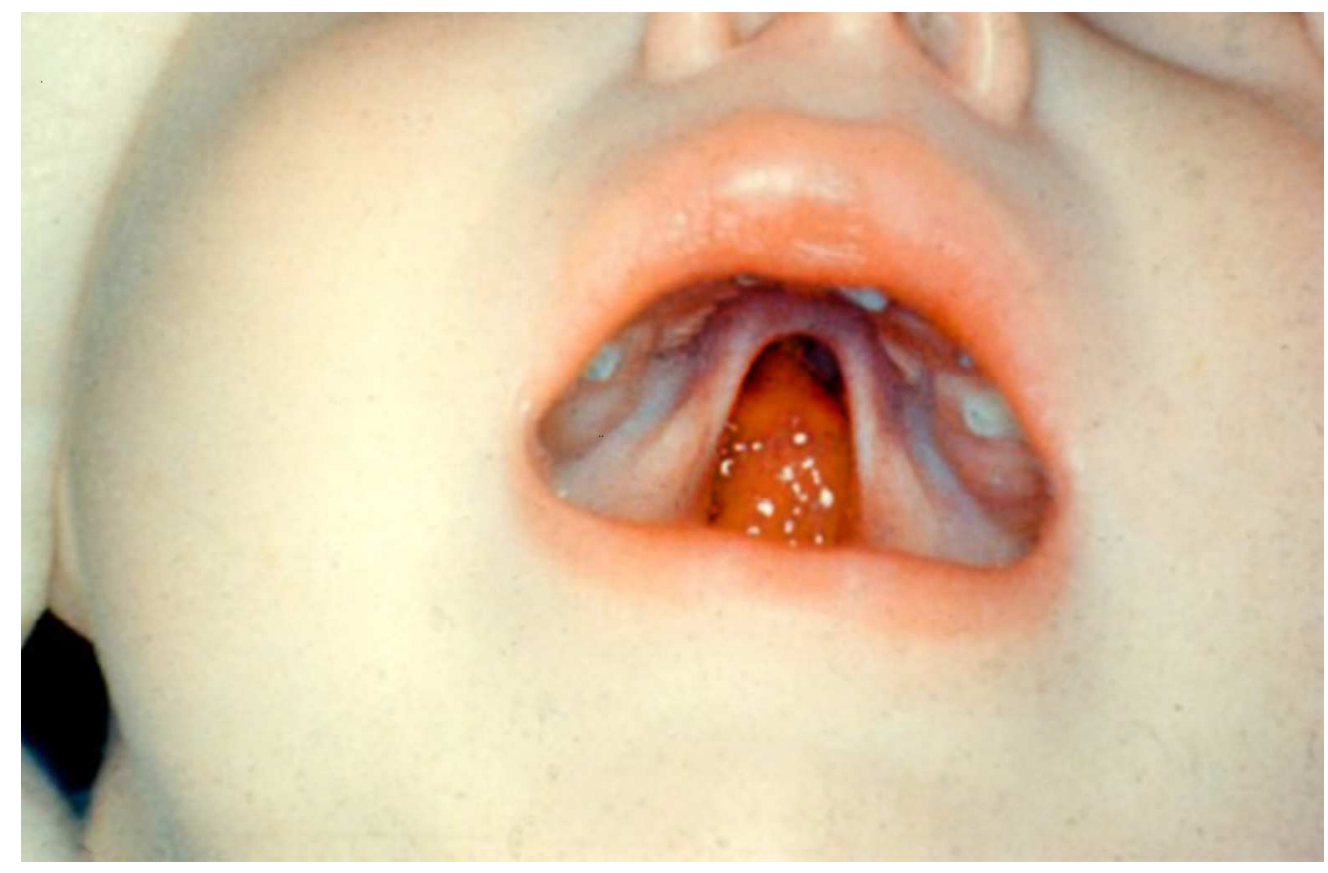

Fig 8: U-shaped cleft palate characteristic of Robin sequence. $150 \times 98 \mathrm{~mm}(300 \times 300$ DPI $)$

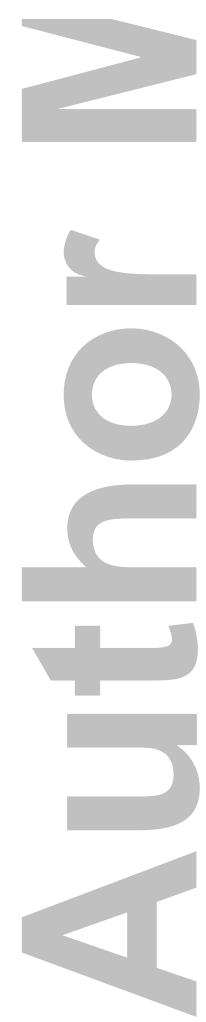

John Wiley \& Sons, Inc.

This article is protected by copyright. All rights reserved. 


\section{University Library}

\section{- M M N E R VA A gateway to Melbourne's research publications}

Minerva Access is the Institutional Repository of The University of Melbourne

\section{Author/s:}

Logjes, RJH;Breugem, CC;Van Haaften, G;Paes, EC;Sperber, GH;van den Boogaard, M$\mathrm{JH} ;$ Farlie, PG

Title:

The ontogeny of Robin sequence

Date:

2018-06-01

\section{Citation:}

Logjes, R. J. H., Breugem, C. C., Van Haaften, G., Paes, E. C., Sperber, G. H., van den Boogaard, M. -J. H. \& Farlie, P. G. (2018). The ontogeny of Robin sequence. AMERICAN JOURNAL OF MEDICAL GENETICS PART A, 176 (6), pp.1349-1368. https://doi.org/10.1002/ ajmg.a.38718.

Persistent Link:

http://hdl.handle.net/11343/284055 